\title{
Trends in $\mathrm{H}_{2} \mathrm{~S}$-Donors Chemistry and Their Effects in Cardiovascular Diseases
}

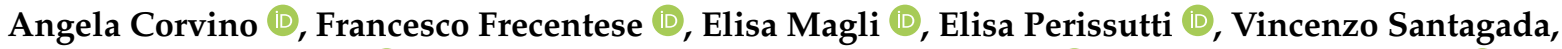

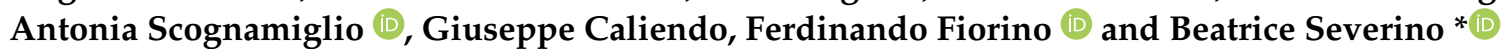

Citation: Corvino, A.; Frecentese, F.; Magli, E.; Perissutti, E.; Santagada, V.; Scognamiglio, A.; Caliendo, G.;

Fiorino, F.; Severino, B. Trends in $\mathrm{H}_{2}$ S-Donors Chemistry and Their Effects in Cardiovascular Diseases. Antioxidants 2021, 10, 429. https:// doi.org/10.3390/antiox10030429

Academic Editor: Daniele Mancard

Received: 17 February 2021

Accepted: 8 March 2021

Published: 11 March 2021

Publisher's Note: MDPI stays neutral with regard to jurisdictional claims in published maps and institutional affiliations.

Copyright: (c) 2021 by the authors. Licensee MDPI, Basel, Switzerland. This article is an open access article distributed under the terms and conditions of the Creative Commons Attribution (CC BY) license (https:// creativecommons.org/licenses/by/ $4.0 /)$.
Department of Pharmacy, School of Medicine, University of Naples Federico II, Via D. Montesano, 49, 80131 Napoli, Italy; angela.corvino@unina.it (A.C.); frecente@unina.it (F.F.); elisa.magli@unina.it (E.M.); perissut@unina.it (E.P.); santagad@unina.it (V.S.); antonia.scognamiglio@unina.it (A.S.); caliendo@unina.it (G.C.); fefiorin@unina.it (F.F.)

* Correspondence: bseverin@unina.it; Tel.: +39-081-679-828

\begin{abstract}
Hydrogen sulfide $\left(\mathrm{H}_{2} \mathrm{~S}\right)$ is an endogenous gasotransmitter recently emerged as an important regulatory mediator of numerous human cell functions in health and in disease. In fact, much evidence has suggested that hydrogen sulfide plays a significant role in many physio-pathological processes, such as inflammation, oxidation, neurophysiology, ion channels regulation, cardiovascular protection, endocrine regulation, and tumor progression. Considering the plethora of physiological effects of this gasotransmitter, the protective role of $\mathrm{H}_{2} \mathrm{~S}$ donors in different disease models has been extensively studied. Based on the growing interest in $\mathrm{H}_{2} \mathrm{~S}$-releasing compounds and their importance as tools for biological and pharmacological studies, this review is an exploration of currently available $\mathrm{H}_{2} \mathrm{~S}$ donors, classifying them by the $\mathrm{H}_{2} \mathrm{~S}$-releasing-triggered mechanism and highlighting those potentially useful as promising drugs in the treatment of cardiovascular diseases.
\end{abstract}

Keywords: hydrogen sulfide; natural $\mathrm{H}_{2} \mathrm{~S}$ donors; synthetic $\mathrm{H}_{2} \mathrm{~S}$ donors; triggered mechanism; $\mathrm{H}_{2} \mathrm{~S}$ release; cardiovascular diseases

\section{Introduction}

Hydrogen sulfide $\left(\mathrm{H}_{2} \mathrm{~S}\right)$, the third endogenous recognized gaseous signaling transmitter [1], among nitric oxide (NO) and carbon monoxide (CO), is a colorless and pungent gas with a boiling point of $60{ }^{\circ} \mathrm{C}$ [2].

It is endogenously synthesized by four enzymes: cystathionine $\gamma$-lyase (CSE) and cystathionine $\beta$-synthetase (CBS), which catalyze the production of $\mathrm{H}_{2} \mathrm{~S}$ by a direct enzymatic desulfhydration of L-cysteine, and 3-mercaptopyruvate sulfurtransferase (3-MST), which produces $\mathrm{H}_{2} \mathrm{~S}$ by an indirect desulfhydration, in concert with cysteine aminotransferase (CAT) and in the presence of reductants [3]. The expression of these enzymes is tissue specific. The amount of CBS is found mostly in the central nervous system, the liver, the kidney, the uterus, and placenta; CSE is primarily concentrated in the cardiovascular system, whereas 3-MST is located predominantly in the mitochondria [4-8].

To study the biological effects of endogenously synthesized $\mathrm{H}_{2} \mathrm{~S}$, the development of inhibitors selective for the above enzymes is required. To date, some selective inhibitors of CSE and CBS have been identified and widely used in biological systems [9-13]; conversely, no pharmacological inhibitors of the enzyme 3-MST have yet been discovered.

Several studies have shown that $\mathrm{H}_{2} \mathrm{~S}$ plays a significant modulatory role in numerous physio-pathological processes in the human body [14]. In fact, it is involved in the homeostatic regulation of respiratory, cardiovascular, immune, nervous, gastroenteric, and endocrine systems $[4,15]$.

Currently, growing research evidence has confirmed the protective effects of $\mathrm{H}_{2} \mathrm{~S}$ in cardiovascular diseases [16-23], such as cardiac hypertrophy, heart failure, myocardial ischemia/reperfusion (I/R) injury [24], hypertension [18,25] and atherosclerosis [26], acting 
as an activator of angiogenesis [27], basal vasorelaxant agent [28], blood pressure, and heart rate regulator $[29,30]$. Moreover, it has been demonstrated that the related mechanisms of action accounting for this cardioprotective activity involve antioxidation, inhibition of cell apoptosis, pro-angiogenesis, anti-inflammatory, and ion channels regulation [31,32] (Figure 1).

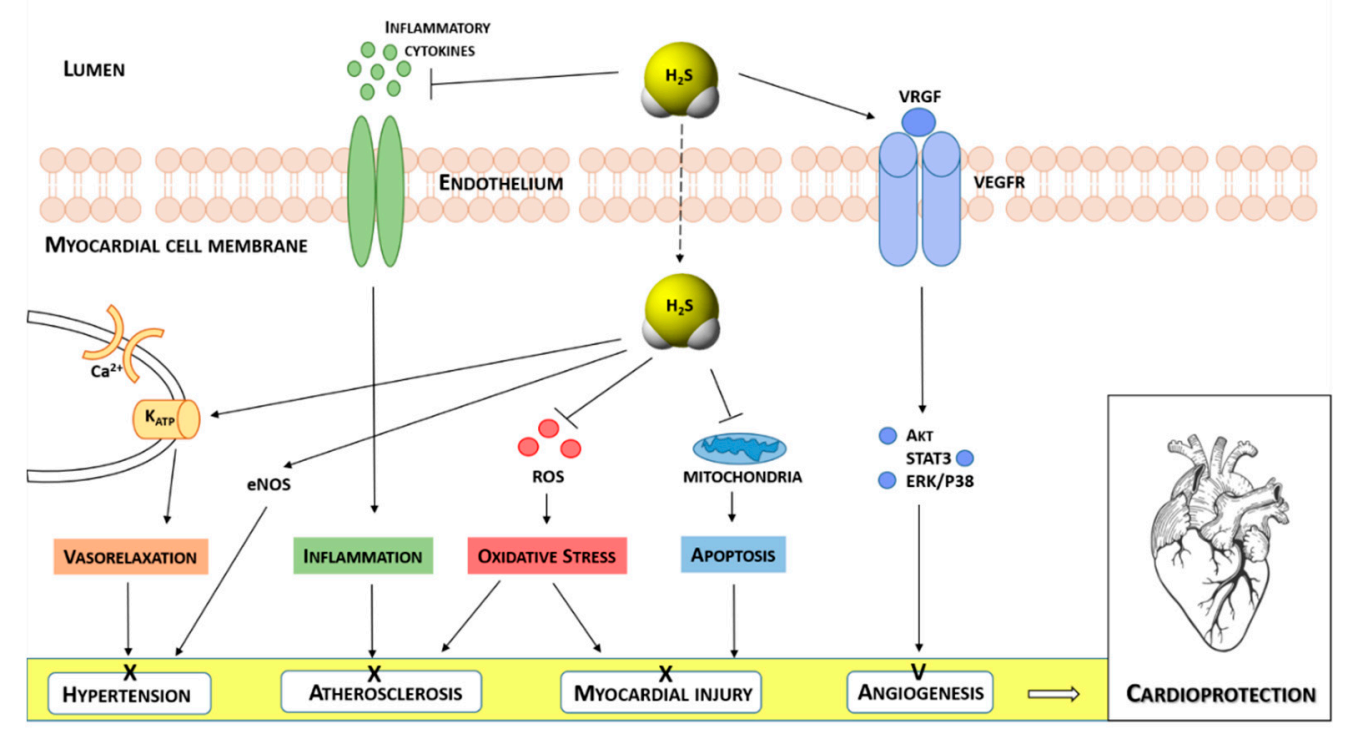

Figure 1. Schematic illustration of the effects of $\mathrm{H}_{2} \mathrm{~S}$ in different heart diseases and the molecular mechanisms underlying $\mathrm{H}_{2} \mathrm{~S}$-induced cardioprotection.

As depicted in Figure $1, \mathrm{H}_{2} \mathrm{~S}$ exerts a cardioprotective effect by activating different endothelium-dependent signaling pathways [33]. It reduces blood pressure, by inducing vasorelaxation, a consequence of opening $\mathrm{K}_{\text {ATP }}$ channels and increasing $\mathrm{K}^{+}$currents resulting in hyperpolarizing membrane of smooth muscle cells [34]. Moreover, $\mathrm{H}_{2} \mathrm{~S}$ shows its anti-hypertensive effect, by activating endothelial nitric oxide synthase (eNOS) and increasing NO bioavailability [35]. It also shows an inhibitory effect on the pathogenesis of atherosclerosis, by preventing an inflammatory response mediated by inflammatory cytokines [26] and exerting antioxidative action through the activation of the nuclear factor erythroid 2-related factor 2 (Nrf2)-dependent pathway and the protection of tissues by reactive oxygen species (ROS). The cardioprotection of $\mathrm{H}_{2} \mathrm{~S}$ is also associated with the inhibition of cardiomyocyte apoptosis after myocardial injury. In fact, it suppresses the activation of caspase-3 and upregulates the expression of glycogen synthase kinase-3 (GSK$3 \beta$ ). The antioxidant effect of $\mathrm{H}_{2} \mathrm{~S}$ is also embodied in the preservation of mitochondrial functions by inhibiting mitochondrial respiration [36].

Furthermore, $\mathrm{H}_{2} \mathrm{~S}$ stimulates angiogenesis by increasing the expression of VEGF and activating some downstream effectors, such as Akt, STAT3, ERK, and p38 [37].

Recently, considering the interesting involvement of $\mathrm{H}_{2} \mathrm{~S}$ in the cardiovascular system, there has been heightened enthusiasm for the development of compounds able to generate exogenous $\mathrm{H}_{2} \mathrm{~S}$, which could represent biological tools and promising cardioprotective agents.

\section{2. $\mathrm{H}_{2} \mathrm{~S}$ Donors}

For the past several years, inorganic sulfide salts, such as sodium sulfide $\left(\mathrm{Na}_{2} \mathrm{~S}\right)$ and hydrosulfide (NaHS), have been commonly used as pharmacological tools. They represent the early $\mathrm{H}_{2} \mathrm{~S}$ donors used in biomedicine field, the results of which make it very useful to elucidate the physio-pathological roles of $\mathrm{H}_{2} \mathrm{~S}$ in mammalian systems.

Although these sulfide salts have been the basic tools used for $\mathrm{H}_{2} \mathrm{~S}$ research for years, some of their significant limitations were demonstrated. In fact, sulfide salts hydrolyze 
immediately upon reaction with water and the resulting too-rapid release of $\mathrm{H}_{2} \mathrm{~S}$ causes its blood and tissue concentrations to surge to supraphysiological levels followed by a rapid drop [38].

Therefore, this suboptimal pharmacokinetic profile led the researchers to limit the use of these salts as potential therapeutics and to obtain novel organic $\mathrm{H}_{2} \mathrm{~S}$-releasing compounds, including chemically synthesized molecules and natural plant extracts.

One of the first slow-releasing $\mathrm{H}_{2} \mathrm{~S}$ donors was Lawesson's reagent, a synthetic compound which is largely used for sulfurization of organic molecules [39]. It has been used in some pharmacological studies as an $\mathrm{H}_{2} \mathrm{~S}$ donor, despite its lack of water solubility.

Therefore, to improve this chemical property, GYY4137, a water-soluble derivative of Lawesson's reagent, was obtained. Similarly to its parent compound, it also releases $\mathrm{H}_{2} \mathrm{~S}$ upon hydrolysis, but it better mimics the physiological $\mathrm{H}_{2} \mathrm{~S}$ production, due to its slow-releasing nature [40,41]. Moreover, in order to optimize the $\mathrm{H}_{2} \mathrm{~S}$ release properties of GYY4137, structural modifications were made to this compound via substitution of the P-C bond in GYY4137 with a P-O bond, affording a series of O-substituted phosphorodithioatebased $\mathrm{H}_{2} \mathrm{~S}$ donors [42].

Later on, naturally occurring $\mathrm{H}_{2} \mathrm{~S}$ donors derived from some vegetables belonging to Alliaceae and Brassicaceae, such as garlic, onion, broccoli, cabbage, watercress, and garden cress, were also investigated.

So far, among garlic-derived compounds, allicin is one of the best characterized. Due to its instability in aqueous media, it quickly decomposes into four $\mathrm{H}_{2} \mathrm{~S}$-releasing compounds: diallyl sulfide (DAS), diallyl disulfide (DADS), diallyl trisulfide (DATS), and ajoene [43].

Other garlic-derived compounds containing a sulfur atom are S-allylcysteine (SAC) with its structural analogs, S-propyl-L-cysteine (SPC), and S-propargyl-cysteine (SPRC), which are potential sources of $\mathrm{H}_{2} \mathrm{~S}$ [44-46].

Similarly, some cruciferous vegetables contain natural isothiocyanates, such as sulforaphane, allyl isothiocyanate, benzyl isothiocyanate, 4-hydroxybenzyl isothiocyanate, and erucin, which exhibit a significant $\mathrm{H}_{2} \mathrm{~S}$-releasing activity [47].

Moreover, it has been demonstrated that some thioamino acids, such as thioglycine and thiovaline, are also $\mathrm{H}_{2} \mathrm{~S}$ donors, showing a slow release of the gasotransmitter [48].

Recently, the limited clinical application of some naturally occurring $\mathrm{H}_{2} \mathrm{~S}$ donors led to the development of novel synthetic compounds with favorable pharmacological properties, which could be useful both as research tools and as potential therapeutics.

Thus, in order to obtain effective $\mathrm{H}_{2} \mathrm{~S}$ donors with controllable release rates, a series of $\mathrm{N}$-(benzoylthio)benzamides [49], acyl perthiols [50,51], arylthioamides [52], 1,2,4thiadiazolidin-3,5-diones [53], iminothioethers [54], mercaptopyruvate [55], dithioates [56], isothiocyanate [57,58], and thiocarbamates [59] were developed and evaluated for their $\mathrm{H}_{2} \mathrm{~S}$-releasing properties.

Each of these donors release $\mathrm{H}_{2} \mathrm{~S}$ with different mechanisms, triggered by hydrolysis, $\mathrm{pH}$ modulation, cellular thiols, photo activation, enzymatic reaction, or others.

\subsection{Sulfide Salts}

Over the years, sulfide salts, such as sodium sulfide $\left(\mathrm{Na}_{2} \mathrm{~S}\right)$ and hydrosulfide (NaHS), have been widely used in biological studies to explore the therapeutic prospects of exogenous source of $\mathrm{H}_{2} \mathrm{~S}$. In particular, these salts showed protective effects against many disease states, such as inflammation [60,61], acute lung injury [62,63], oxidative stress in human neuroblastoma cells [64], Alzheimer's disease (AD) [65], atherosclerosis [66], and ulcer $[67,68]$.

In addition to these effects, aqueous $\mathrm{NaSH}$ solutions delivered in aortic rings led to a $60 \%$ greater relaxation over controls, confirming the vasorelaxant properties of $\mathrm{H}_{2} \mathrm{~S}$ [28].

Moreover, several groups demonstrated that the use of sulfide salts was able to induce either pre- and post-conditioning cardioprotection [25,69-73]. 
Exogenous NaHS has proven to be useful in attenuating ischemia-reperfusion injury [74], protecting against myocardial infarction (MI) [75] and hemorrhagic shock [76].

Furthermore, Calvert et al. reported that long-term $\mathrm{Na}_{2} \mathrm{~S}$ administration attenuates ischemia-induced heart failure, by reducing oxidative stress [24]. The results suggested that the $\mathrm{H}_{2} \mathrm{~S}$ therapy attenuates left ventricular (LV) dilation and cardiac hypertrophy, and leads to an improvement in cardiac function.

Solutions of these sulfide salts are prepared by using hydrates of sodium hydrogen sulfide ( $\left.\mathrm{NaHS} \times \mathrm{nH}_{2} \mathrm{O}\right)$, nonahydrate disodium salt $\left(\mathrm{Na}_{2} \mathrm{~S} \times 9 \mathrm{H}_{2} \mathrm{O}\right)$, or the anhydrous form.

In water or aqueous solution, these sulfide salts quickly hydrolyze, establishing a dynamic equilibrium among sulfide ions $\left(\mathrm{S}^{2-}\right)$, bisulfide ions $\left(\mathrm{HS}^{-}\right)$, and molecular hydrogen sulfide $\left(\mathrm{H}_{2} \mathrm{~S}\right)$ [77] (Figure 2); the ratio of these species depends on different parameters, such as temperature, pressure, and $\mathrm{pH}$.

$$
\begin{aligned}
& \mathrm{Na}_{2} \mathrm{~S}+2 \mathrm{H}_{2} \mathrm{O} \rightleftharpoons 2 \mathrm{Na}^{+}+2 \mathrm{OH}^{-}+\mathrm{H}_{2} \mathrm{~S}_{(\text {aq) }} \\
& \mathrm{NaHS}+2 \mathrm{H}_{2} \mathrm{O} \rightleftharpoons \mathrm{Na}^{+}+2 \mathrm{OH}^{-}+\mathrm{H}_{2} \mathrm{~S}_{(\mathrm{aq})} \\
& \mathrm{H}_{2} \mathrm{~S}_{(\text {aq })} \rightleftharpoons \mathrm{HS}^{-}+\mathrm{H}^{+} \rightleftharpoons \mathrm{S}^{2-}+2 \mathrm{H}^{+}
\end{aligned}
$$

Figure 2. Mechanism of $\mathrm{H}_{2} \mathrm{~S}$ release from $\mathrm{Na}_{2} \mathrm{~S}(\mathbf{1 a})$ and $\mathrm{NaHS}(\mathbf{1 b})$ in aqueous solution and its dynamic equilibrium among different species (2).

As the $\mathrm{pH}$ increases, the $\mathrm{H}_{2} \mathrm{~S}$ dissociates into its ions. At a pH below $6, \mathrm{H}_{2} \mathrm{~S}$ is the predominant sulfur species; at the physiological $\mathrm{pH}, \mathrm{H}_{2} \mathrm{~S}$ and $\mathrm{HS}^{-}$species are both present in solution in the ratio of 1:3; at a $\mathrm{pH}$ of $\sim 9 \mathrm{HS}^{-}$is fully formed, while at a $\mathrm{pH}$ above 15 , $\mathrm{S}^{2-}$ is the predominant species.

\subsection{Naturally Occurring Donors}

Currently available $\mathrm{H}_{2} \mathrm{~S}$-releasing compounds can be divided into two groups: naturally occurring donors and synthetic donors. Among the natural source, allium family and cruciferous vegetables are recognized to be rich in organosulfur compounds.

In particular, garlic contains at least thirty-three sulfur compounds, a concentration higher than any other allium species. The organosulfides in the allium family are represented by oil-soluble polysulfides and water-soluble thiosulfinates and appear to be responsible for many garlic's medicinal effects. It has been demonstrated that the allicin, one of the biologically active components in garlic, and its principal transformation products, which are organic polysulfides, provide a critical role in garlic-induced cardioprotection [78-81].

In fact, it has been demonstrated that these compounds are responsible for lowering the arterial blood pressure, reducing the serum cholesterol and triglycerides, inhibiting the platelet aggregation, preventing the atherosclerosis, increasing the fibrinolytic activity, and reducing the oxidative stress [82].

Among Cruciferae, vegetables such as broccoli, watercress, mustard, and garden cress are rich in isothiocyanates, such as sulforaphane (SFN, highly present in broccoli), allyl isothiocyanate (AITC, highly present in black mustard), benzyl isothiocyanate (BITC, highly present in garden cress), 4-hydroxybenzyl isothiocyanate (HBITC, highly present in white mustard), and erucin (ERU, mainly present in broccoli and rocket) (Figure 3).

Recently, it has been demonstrated that these secondary metabolites of Brassicaceae, derived from corresponding glucosinolates upon the enzymatic action of myrosinase, show $\mathrm{H}_{2} \mathrm{~S}$-releasing properties. This finding shed light on the mechanism of action of Brassicaceae and on the role of hydrogen sulfide as relevant player for their nutraceutical and pharmaceutical effects [47]. 


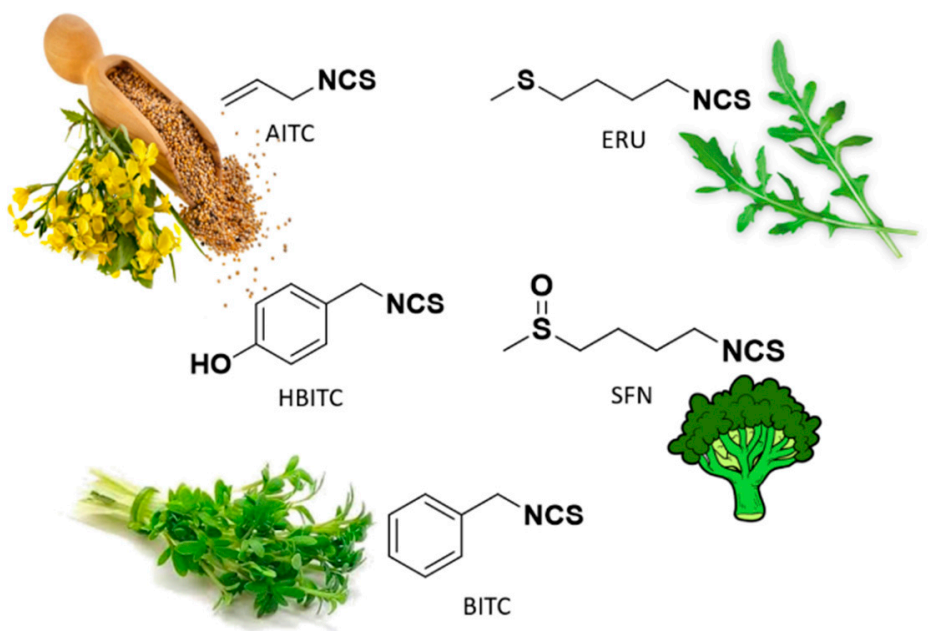

Figure 3. Chemical structures of natural isothiocyanates, which are abundant in cruciferous vegetables.

Based on the mechanism of release, the above compounds belong to thiol-triggered donors; in fact, they react with the thiol groups of glutathione (GSH) or cysteine to release free $\mathrm{H}_{2} \mathrm{~S}$.

In the intact garlic, the primary sulfur compounds are the $\gamma$-glutamyl-S-alk(en)ylL-cysteines which can be hydrolyzed and oxidized to yield alliin. Alliinase accounts for the conversion of alliin to allicin. The latter is highly instable in aqueous media and instantly decomposes, forming some oil-soluble compounds, such as diallyl sulfide (DAS), diallyl disulfide (DADS), diallyl trisulfide (DATS), and ajoene [43]. These allicin-derived compounds led to $\mathrm{H}_{2} \mathrm{~S}$ generation upon reaction with endogenous thiols, such as L-cysteine and GSH.

Furthermore, $\gamma$-glutamyl-S-alk(en)yl-L-cysteines can be also converted to watersoluble organosulfur compounds including S-allyl cysteine (SAC) and S-allyl mercaptocysteine (SAMC) (Figure 4).

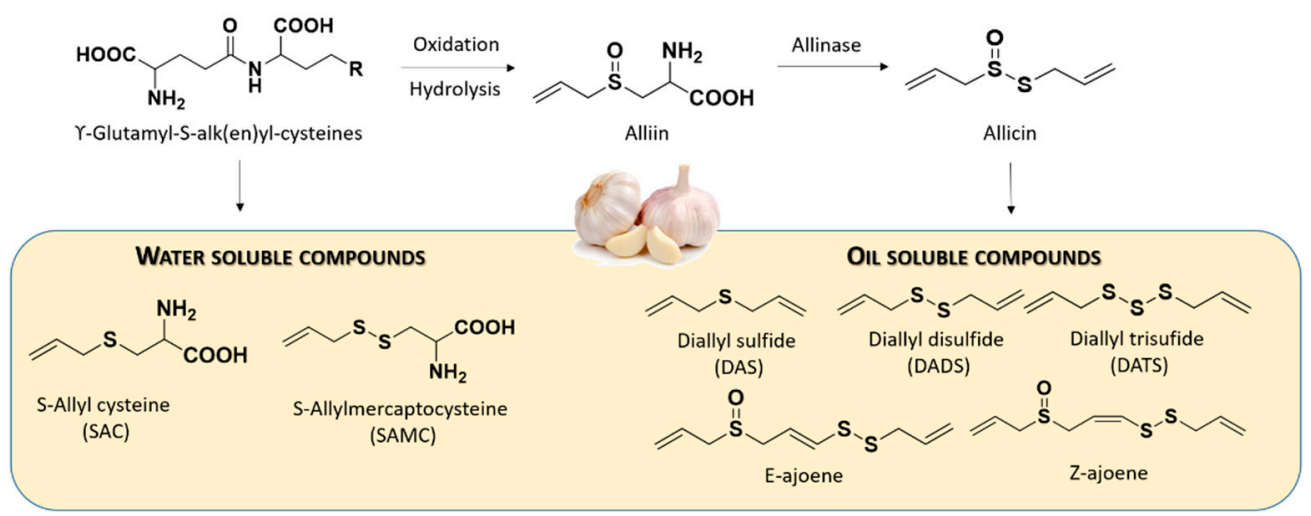

Figure 4. Chemical structures of commonly studied organosulfur compounds of garlic.

SAC, a sulfur-containing amino acid, was considered an endogenous $\mathrm{H}_{2} \mathrm{~S}$-producing agent by providing the substrate for CSE in the $\mathrm{H}_{2} \mathrm{~S}$ synthesis (Figure $\mathrm{S} 1$ ).

It is responsible for many important activities, such as antioxidative [83,84], anticancer $[85,86]$, anti-hepatotoxic $[87,88]$, and cardioprotective activities [89]. In particular, it showed a cardiovascular protective role in MI by decreasing lipid peroxide products and improving the antioxidant status. Indeed, Chuah et al. also demonstrated that SAC could upregulate the expression of CSE, leading to enhanced $\mathrm{H}_{2} \mathrm{~S}$ release. The increased 
$\mathrm{H}_{2} \mathrm{~S}$ concentration in the myocardial and plasma is responsible for cardioprotection during acute MI [90].

Moreover, it was reported that S-propargyl-cysteine (SPRC) and S-propyl-cysteine (SPC) (Figure S1) also exhibited cardioprotective effects, via CSE/ $\mathrm{H}_{2} \mathrm{~S}$ pathway [91,92].

Among the oil-soluble components of garlic, the major organosulfur compounds were reported to be DADS and DATS. In 2007, Benavides et al. demonstrated that these compounds could release $\mathrm{H}_{2} \mathrm{~S}$ rapidly through a thiol-dependent mechanism [93] (Figure 5). In the presence of GSH, DADS can react with it to generate S-allyl glutathione (GSA) and the intermediate allyl perthiol (ASSH), which reacts with another GSH to produce $\mathrm{H}_{2} \mathrm{~S}$ and S-allyl glutathione disulfide (GSSA). Furthermore, the latter compound could also undergo $\alpha$-carbon nucleophilic substitution, generating $\mathrm{H}_{2} \mathrm{~S}$ rapidly [78] (Figure 5a). This mechanism has been widely confirmed [33,94-99], except for the rate of $\mathrm{H}_{2} \mathrm{~S}$ release from DADS. Regarding this topic, in fact, Liang and co-workers demonstrated that DADS releases $\mathrm{H}_{2} \mathrm{~S}$ very slowly through $\alpha$-carbon nucleophilic substitution. The explanation of the previous misunderstanding of DADS as a fast $\mathrm{H}_{2} \mathrm{~S}$ donor is DATS contamination in commercial samples of DADS; in fact, among these compounds, DATS is responsible for the rapid $\mathrm{H}_{2} \mathrm{~S}$ release.
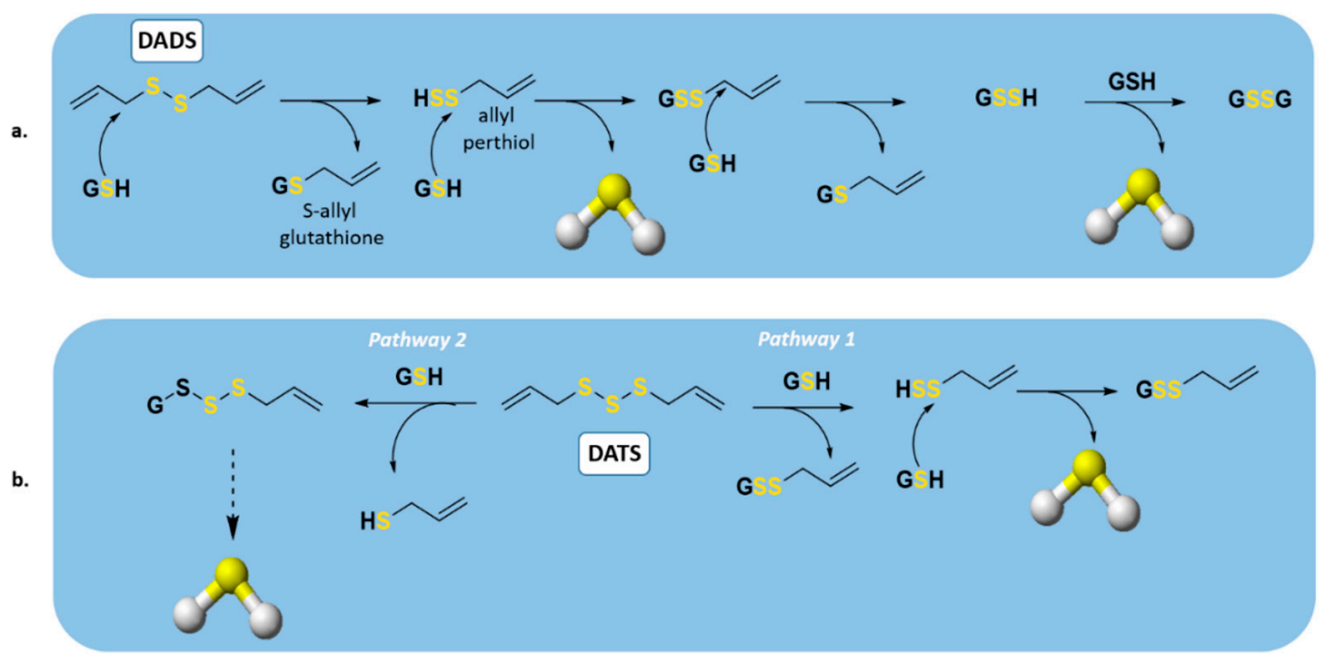

Figure 5. $\mathrm{H}_{2} \mathrm{~S}$ production from organic polysulfides by thiol reactions. Proposed mechanism of $\mathrm{H}_{2} \mathrm{~S}$ production from (a) diallyl disulfide (DADS) and (b) diallyl trisulfide (DATS).

Regarding DATS (Figure 5b), two possible thiol-disulfide exchange reaction pathways can occur. Firstly (pathway 1), the nucleophilic attack of GSH on allylic sulfur of DATS can generate GSSA and ASSH, with the latter able to be reduced by GSH and thus releasing $\mathrm{H}_{2} \mathrm{~S}$; on the other side (pathway 2), the nucleophilic attack of GSH on the central sulfur atom of DATS can lead to the production of ASH and GSSSA. The latter can generate $\mathrm{H}_{2} \mathrm{~S}$ rapidly.

Currently, isothiocyanates are also drawing a lot of attention for their many biological and pharmacological effects in the prevention of important human diseases, such as cancer, neurodegenerative processes, and cardiovascular diseases [100]. In particular, Martelli et al. demonstrated that some selected aryl isothiocyanates were able to release $\mathrm{H}_{2} \mathrm{~S}$ in a biological environment and produce a vasorelaxant effect in rat aortic rings, strongly antagonized by a specific Kv7-blocker, and in the coronary vascular bed, causing an increase of basal coronary flow [57]. Furthermore, the $\mathrm{H}_{2} \mathrm{~S}$-releasing properties of the secondary metabolites of Brassicaceae, isothiocyanates, are also derived from the rapid reaction with thiols, such as cysteine (Figure 6). 

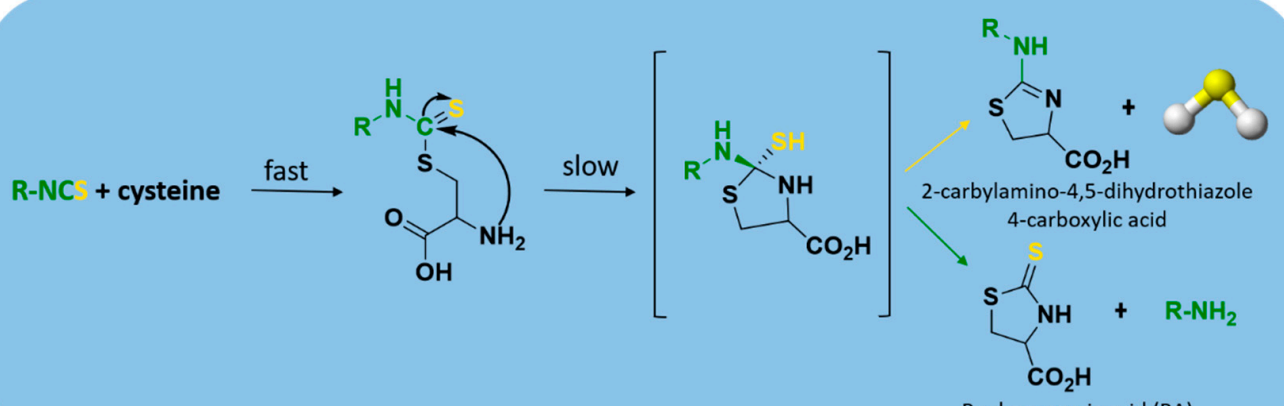

Raphanusamic acid (RA)

Figure 6. The mechanism of $\mathrm{H}_{2} \mathrm{~S}$ release from isothiocyanates.

The formed Cys-ITC adduct undergo intramolecular cyclization followed by releasing organic amine $\mathrm{R}-\mathrm{NH}_{2}$ and raphanusamic acid (RA), on one hand, and $\mathrm{H}_{2} \mathrm{~S}$ and 2-carbylamino-4,5-dihydrothiazole-4-carboxylic acid, on the other hand [101].

\subsection{Synthetic Donors}

Although naturally occurring $\mathrm{H}_{2} \mathrm{~S}$ donors represent an attractive tool for in vivo studies, their poor toxicity and the tendency of these compounds to also generate some byproducts, which are not related to $\mathrm{H}_{2} \mathrm{~S}$ production, led researchers to develop novel synthetic $\mathrm{H}_{2} \mathrm{~S}$ donors with more favorable pharmacokinetic and safety profiles.

Based on their mechanism of $\mathrm{H}_{2} \mathrm{~S}$ release, we have classified the synthetic compounds into different groups: hydrolysis-triggered donors, $\mathrm{pH}$-controllable $\mathrm{H}_{2} \mathrm{~S}$ donors, thioltriggered donors, enzyme-triggered donors, and others (Table 1).

Table 1. $\mathrm{H}_{2}$ S-releasing molecules in cardiovascular system.

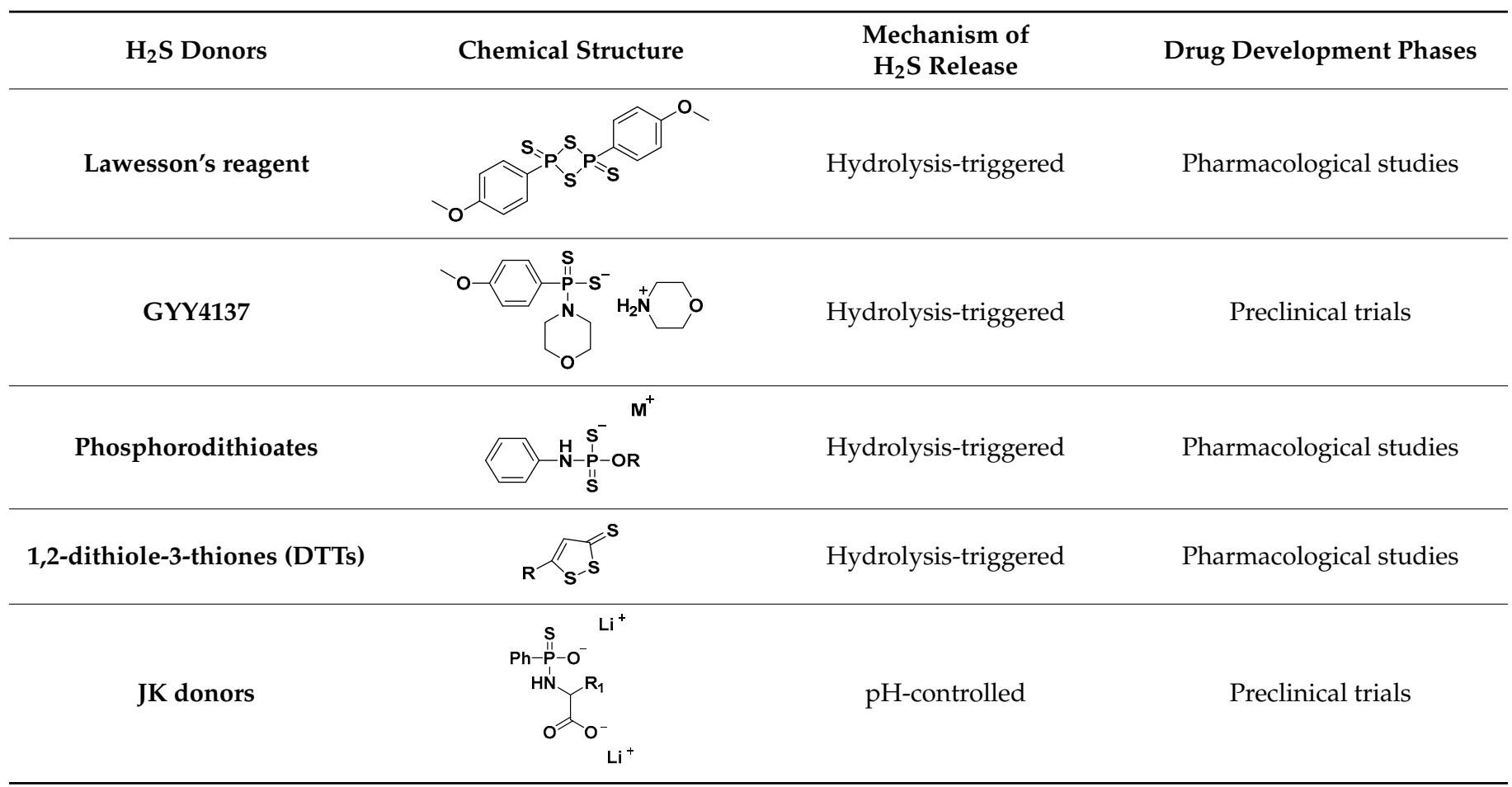


Table 1. Cont.

\begin{tabular}{|c|c|c|c|}
\hline $\mathrm{H}_{2} \mathrm{~S}$ Donors & Chemical Structure & $\begin{array}{l}\text { Mechanism of } \\
\mathrm{H}_{2} \mathrm{~S} \text { Release }\end{array}$ & Drug Development Phases \\
\hline $\begin{array}{l}\text { Ammonium } \\
\text { tetrathiomolybdate (ATTM) }\end{array}$ & $\left(\mathrm{NH}_{4}\right)_{2} \mathrm{MoS}_{4}$ & $\mathrm{pH}$-controlled & $\begin{array}{c}\text { Phase I and II clinical trials } \\
\text { for breast cancer }\end{array}$ \\
\hline N-Benzoylthiobenzamides & & Thiol-triggered & Pharmacological studies \\
\hline Acyl perthiols & & Thiol-triggered & Preclinical trials \\
\hline Dithioperoxyanhydrides & & Thiol-triggered & Pharmacological studies \\
\hline Arylthioamides & & Thiol-triggered & Preclinical trials \\
\hline Arylisothiocyanates & $\mathrm{Ar}^{-1}$ & Thiol-triggered & Pharmacological studies \\
\hline $\begin{array}{l}\text { 1,2,4-Thiadiazolidine } \\
\text {-3,5-diones }\end{array}$ & & Thiol-triggered & Pharmacological studies \\
\hline SG-1002 & & Thiol-triggered & $\begin{array}{l}\text { Phase I clinical trial complete } \\
\text { for heart failure }\end{array}$ \\
\hline Trimethyl lock (TML) & & Enzyme-triggered & Pharmacological studies \\
\hline $\begin{array}{c}\text { N-Thiocarboxyanhydrides } \\
\text { (NTAs) }\end{array}$ & & Enzyme-triggered & Preclinical trials \\
\hline PeroxyTCM & & $\begin{array}{l}\text { Enzyme-triggered } \\
\text { ROS-triggered }\end{array}$ & Preclinical trials \\
\hline Thioamino acids & & Bicarbonate-triggered & Pharmacological studies \\
\hline ZYZ803 & & CSE/eNOS-dependent & Preclinical trials \\
\hline Zofenopril & & ACE inhibitor & Clinical use for CVD \\
\hline
\end{tabular}


Table 1. Cont.

ACS 14

\subsubsection{Hydrolysis-Triggered Donors}

Morpholin-4-ium-4-methoxyphenyl(morpholino)phosphinodithioate (GYY4137), a water-soluble Lawesson's reagent derivative (Figure S2), is one of the first slow-releasing $\mathrm{H}_{2} \mathrm{~S}$ donors developed $[40,41,102]$ and the most commonly used research tool to investigate the role of $\mathrm{H}_{2} \mathrm{~S}$ in the biological systems.

GYY4137 was synthesized starting from Lawesson's reagent, previously obtained by heating a mixture of anisole with phosphorus pentasulfide (P4S10) $[103,104]$, which reacts with morpholine in dichloromethane at room temperature (Figure S3) [40].

Much evidence has revealed that GYY4137 exhibits anti-inflammatory, antioxidant, and anticancer properties [52].

It also activates vascular smooth muscle $\mathrm{K}_{\mathrm{ATP}}$ channels, and relaxes rat aortic rings and renal blood vessels, showing its anti-hypertensive activity [40].

Moreover, GYY4137 has been reported to inhibit microvascular thrombus formation and to stabilize atherosclerosis plaque by interfering with platelet activation and adhesion molecule-mediated aggregation [105]. It also protects against diabetic myocardial I/R injury, through activation of the PHLPP-1/Akt/Nrf2 pathway [106].

It has been demonstrated that GYY4137 slowly releases $\mathrm{H}_{2} \mathrm{~S}$ upon hydrolysis [40]. In 2015, Alexander et al. carefully studied the hydrolysis kinetics of GYY4137, monitoring it by a combination of NMR spectroscopy and mass spectrometry [107]. Firstly, a sulfuroxygen exchange with water occurs, leading to the release of $\mathrm{H}_{2} \mathrm{~S}$. The formed product, an aryl-phosphonamidothioate, undergoes complete hydrolysis to release a second molecule of $\mathrm{H}_{2} \mathrm{~S}$ (Figure $\mathrm{S} 4$ ).

Despite GYY4137 having been proven to be a useful biological tool, it suffers from some drawbacks, such as its contamination with traces of dichloromethane residual from crystallization and the slow hydrolysis rate. These aspects could make the attribution of biological effects to GYY4137-derived $\mathrm{H}_{2} \mathrm{~S}$ uncertain, because of the possible simultaneous metabolization of dichloromethane to $\mathrm{CO}$, which has biological effects like $\mathrm{H}_{2} \mathrm{~S}$ [108].

Therefore, structural modifications of GYY4137 were designed and the resulting analogs were studied. Park and coworkers developed a series of O-aryl- and alkylsubstituted phosphorodithioates as $\mathrm{H}_{2} \mathrm{~S}$ donors, by replacing the P-C bond in GYY4137 with O-substitution [42] (Figure S2). Their studies evidenced that the gaseous release from these novel $\mathrm{H}_{2} \mathrm{~S}$ donors did not significantly improve. In fact, similarly to the parent compound GYY4137, O-arylated donors showed slow $\mathrm{H}_{2} \mathrm{~S}$ production, whereas O-alkylated donors exhibited very weak $\mathrm{H}_{2} \mathrm{~S}$ generation.

Another class of compounds belonging to the family of hydrolysis-triggered $\mathrm{H}_{2} \mathrm{~S}$ donors are 1,2-dithiole-3-thiones (DTTs) (Figure S2).

DTT compounds are anethole dithiolethione (ADT) and its O-demethylated derivative ADT-OH [5-(p-hydroxyphenyl)-3H-1,2-dithiole-3-thione], which were largely used as $\mathrm{H}_{2} \mathrm{~S}$ donors (Figure S5). 
To obtain DTTs, different methods can be applied. The most used synthetic strategy provides dehydrogenation and sulfurization of an allylic methyl group, by treating it with elemental sulfur or phosphorus pentasulfide products [109] (Figure S6). Alternatively, $\beta$-ketoesters could react with Lawesson's reagent to give the desired DTTs $[110,111]$ (Figure S6).

To date, several groups have studied the biological effects of ADT and ADT-OH, observing an important activity related to the $\mathrm{H}_{2} \mathrm{~S}$-releasing properties of these compounds. ADT is an FDA-approved drug, which can stimulate bile secretion, restoring salivation and relieving dry mouth in patients affected by chemotherapy-induced xerostomia [112]. Additionally, its derivative, ADT-OH, resulted in being useful for reducing cell viability via inhibition of histone deacetylase [113,114] and NF-kB activation [115].

Although their $\mathrm{H}_{2} \mathrm{~S}$-releasing mechanism is still not completely defined, it is widely accepted that the production of $\mathrm{H}_{2} \mathrm{~S}$ from DTTs occurs via hydrolysis $[34,116,117]$ (Figure S7). Indeed, it has been demonstrated that upon heating to $120^{\circ} \mathrm{C}$ in aqueous solution, dithiolethione derivatives gradually release $\mathrm{H}_{2} \mathrm{~S}$, converting into the corresponding 1,2-dithiole3-one [39].

Interestingly, $\mathrm{H}_{2} \mathrm{~S}$ donor hybrids were obtained by coupling the $\mathrm{OH}$ group of ADT-OH with some commercially available drugs and the resulting compounds were studied for their $\mathrm{H}_{2} \mathrm{~S}$-releasing properties and therapeutic effects [118].

They are usually synthesized by coupling the active compounds with ADT-OH in the presence of $\mathrm{N}, \mathrm{N}^{\prime}$-dicyclohexylcarbodiimide (DCC) and 4-dimethylaminopyridine (DMAP) (Figure S8) [119]. These $\mathrm{H}_{2} \mathrm{~S}$ donor hybrids exhibited their efficacy in many pharmacological fields, such as inflammation [120,121] $\left(\mathrm{H}_{2} \mathrm{~S}-\right.$ donating diclofenac, ACS-15/ATB337; $\mathrm{H}_{2} \mathrm{~S}$-donating mesalamine, ATB-429), cancer [122] ( $\mathrm{H}_{2} \mathrm{~S}$-donating sulindac, HS-SUL; $\mathrm{H}_{2} \mathrm{~S}$-donating aspirin, HS-ASA / ACS-14; $\mathrm{H}_{2} \mathrm{~S}$-donating ibuprofen, HS-IBU; $\mathrm{H}_{2} \mathrm{~S}$-donating naproxen, HS-NAP), erectile dysfunction [123] ( $\mathrm{H}_{2} \mathrm{~S}$-donating sildenafil, ACS 6), neurodegeneration $\left(\mathrm{H}_{2} \mathrm{~S}\right.$-donating latanoprost, ACS 67, for glaucoma treatment [124], and $\mathrm{H}_{2} \mathrm{~S}$-donating levodopa, ACS 83, for Parkinson's disease [125]), and cardioprotection $\left(\mathrm{H}_{2} \mathrm{~S}\right.$-donating aspirin, HS-ASA/ACS 14, and AP-39) (Figure 7).

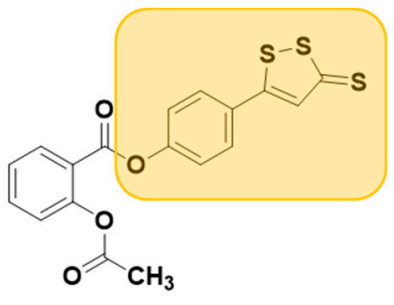

HS-ASA/ACS 14

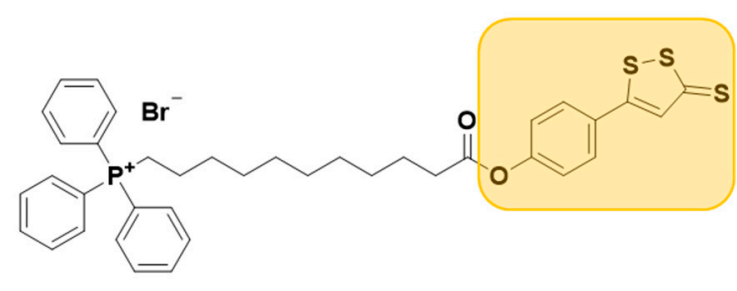

AP-39

Figure 7. Chemical structures of $\mathrm{H}_{2} \mathrm{~S}$ donor hybrids involved in cardiovascular disease.

Indeed, Rossoni and co-workers demonstrated that ACS14 exerts strong protective effects against buthionine sulfoximine (BSO)-induced cardiovascular diseases, by increasing systolic blood pressure and lowering heart rates in rats [126]. Additionally, oral administration of ACS 14 reduces BSO-induced hypertensive effects, unlike aspirin which has no effect. Moreover, ACS 14 treatment in BSO rats reduces myocardial I/R injury [126-128].

More recently, another hybrid $\mathrm{H}_{2} \mathrm{~S}$ donor, named AP-39, resulting from the reaction of triphenylphosphonium with ADT-OH, was developed [129] and studied for its $\mathrm{H}_{2} \mathrm{~S}-$ releasing properties and potential pharmacological effects.

AP-39 significantly inhibits oxidative stress-induced toxicity and protects against acute cardiac arrest, renal, and myocardial I/R injury, by inhibiting the mitochondrial permeability transition pore [130-133]. 


\subsection{2. $\mathrm{pH}$-Controllable $\mathrm{H}_{2} \mathrm{~S}$ Donors}

Starting from GYY4137 structure, Kang and coworkers developed a series of phosphonamidothioates, named JK donors [134].

To synthesize these compounds, the phenylphosphonothioic dichloride was treated with 3-hydroxypropionitrile and, consequently, with a selected C-protected amino acid, such as glycine, phenylalanine, valine, alanine, and proline. These steps provided the intermediate, which underwent $\mathrm{LiOH}$-mediated hydrolysis, furnishing the final compounds (Figure S9).

These donors represent the first class of $\mathrm{pH}$-controllable $\mathrm{H}_{2} \mathrm{~S}$ donors. Indeed, in aqueous media under acidic conditions $(\mathrm{pH}=2.0-6.0)$, JK donors had higher $\mathrm{H}_{2} \mathrm{~S}$ release rates, whereas at neutral and mildly basic $\mathrm{pH}(7.4-8.0)$, they caused slower and less $\mathrm{H}_{2} \mathrm{~S}$ release.

Kang and co-workers observed that these donors undergo a new hydrolysis mechanism of release. The protonation of phosphonamidothioates leads to the formation of the corresponding phosphorothiols, which cyclize via nucleophilic addition of the carboxylic acid group, resulting in breakage of the P-S bond and in release of $\mathrm{H}_{2} \mathrm{~S}$ (Figure 8).

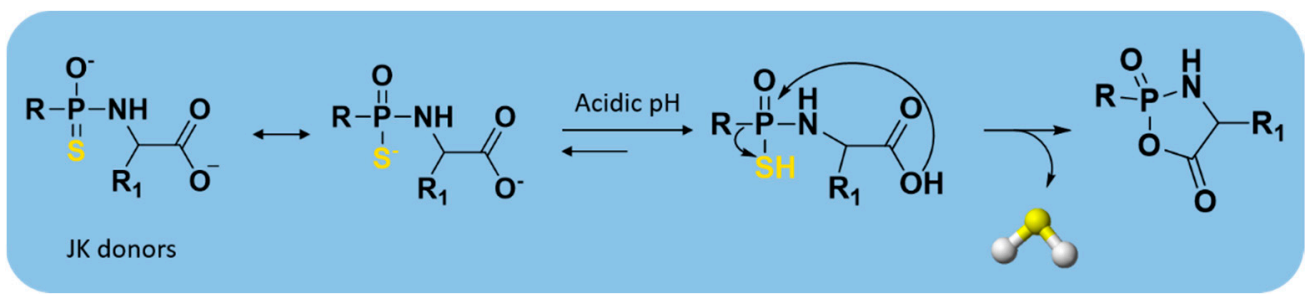

Figure 8. $\mathrm{H}_{2} \mathrm{~S}$-releasing mechanism from JK donors.

Moreover, the two main donors (JK-1 and JK-2) of the series (Figure S10) showed protective effects on cellular and murine models of myocardial I/R injury. They were also successful in reducing infarct size and circulating troponin-I level significantly [134].

Furthermore, ammonium tetrathiomolybdate (ATTM), an excellent copper chelator with the formula $\left(\mathrm{NH}_{4}\right)_{2} \mathrm{MoS}_{4}$, was identified as a pH-dependent $\mathrm{H}_{2} \mathrm{~S}$ donor [135]. Indeed, it has been demonstrated that $\mathrm{H}_{2} \mathrm{~S}$ can be generated from ATTM under strong acidic conditions $\left(5 \% \mathrm{H}_{2} \mathrm{SO}_{4}\right)$ (Figure $\left.\mathrm{S} 11\right)$.

Later, $\mathrm{Xu}$ and co-workers described ATTM as a water-soluble and a pH-sensitive slowreleasing $\mathrm{H}_{2} \mathrm{~S}$ donor [136]. More recently, it has been found that ATTM exerts protective effects on the heart and brain in rat models of myocardial and cerebral I/R injury and attenuates I/R injury [137].

Considering that some preclinical data suggested that $\mathrm{H}_{2} \mathrm{~S}$ is responsible for protective effects in doxorubicin- and adriamycin-induced cardiomyopathy during cancer therapies [138-140] and that ATTM is currently in clinical trials for the treatment of breast cancer due to its copper depletion effects [141], the researchers are studying the potential dual role of ATTM as an anticancer and cardioprotective agent in patients with cancer treated with doxorubicin or adriamycin.

\subsubsection{Thiol-Triggered Donors}

Thiol-activated $\mathrm{H}_{2} \mathrm{~S}$-releasing compounds were some of the first synthetic donors to be reported. They can release $\mathrm{H}_{2} \mathrm{~S}$ by reacting with endogenous thiol-containing molecules, such as GSH, which are relatively abundant in mammals. Some of these $\mathrm{H}_{2} \mathrm{~S}$ donors were found to exhibit protective effects in cardiovascular diseases (Figure S12).

Among the first nucleophile-triggered $\mathrm{H}_{2} \mathrm{~S}$ donors, a series of $\mathrm{N}$-(benzoylthio) benzamides were synthesized by Zhao et al. [49] with the goal of developing compounds which are stable in aqueous solution. The $\mathrm{N}$-(acylthiol)benzamide derivatives were prepared by treating thiocarboxylic acids with hydroxylamine-O-sulfonic acid under basic condi- 
tions; the following reaction between the obtained S-acylthiohydroxylamines and benzoic anhydride led to obtain the final products (Figure S13).

The resulting compounds were proven to be stable in aqueous buffers and to be able to release $\mathrm{H}_{2} \mathrm{~S}$ only following a nucleophilic attack by thiols. The structure-activity relationship studies showed that electron withdrawing groups cause a faster $\mathrm{H}_{2} \mathrm{~S}$ release, unlike electron donating groups. In addition, $\mathrm{H}_{2} \mathrm{~S}$ release from $\mathrm{N}$-(benzoylthio)benzamides was also detected in the plasma, revealing that $\mathrm{N}-\mathrm{SH}$ compounds have efficacy in complex systems.

These compounds protect human keratinocytes against methylglyoxal (MGO)-induced cell damage and dysfunction, which is prevalent among patients with diabetes mellitus [142]. Moreover, they were evaluated in animal models of myocardial I/R injury. The reduction in infarct size over controls in murine models indicated N-(benzoylthio)benzamides as cardioprotective agents [143].

The thiol-triggered mechanism of release from these $\mathrm{H}_{2} \mathrm{~S}$ donors starts with a thioester exchange between the donor and a first molecule of cysteine generating S-benzoyl cysteine and N-mercaptobenzamide, an N-SH intermediate (Figure 9).

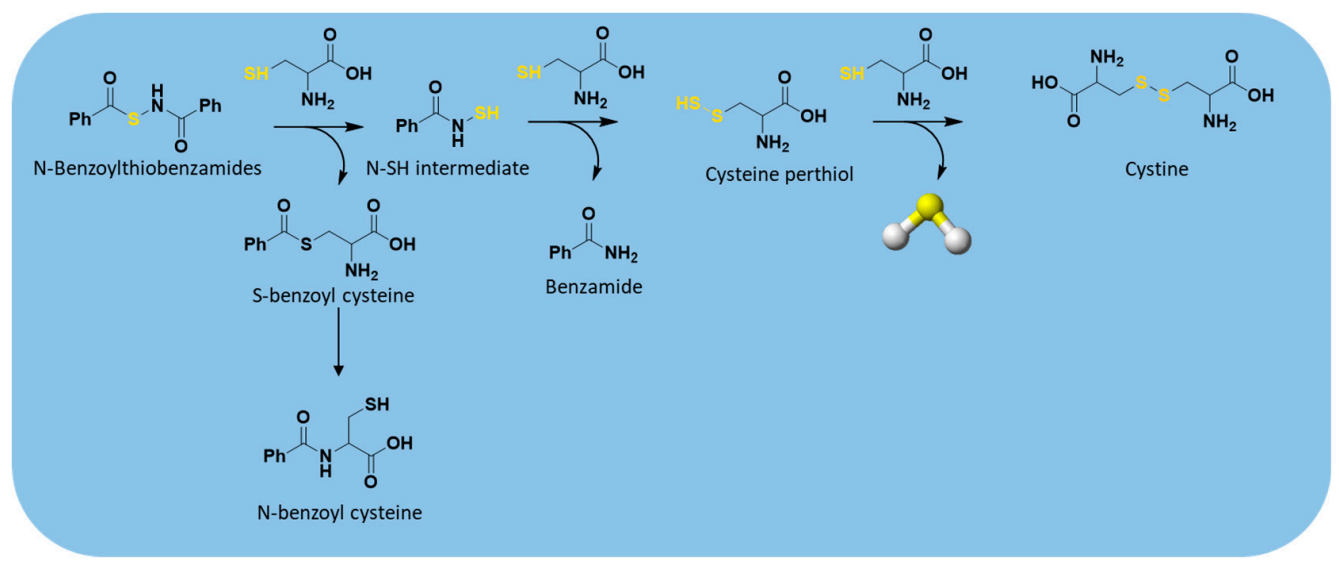

Figure 9. $\mathrm{H}_{2} \mathrm{~S}$ release from N-benzoylthiobenzamides.

The resulting S-benzoyl cysteine, due to its high reactivity, undergoes a fast $\mathrm{S}$ to $\mathrm{N}$ acyl transfer, leading to the formation of a more stable N-benzoyl cysteine. At the same time, the formed $\mathrm{N}-\mathrm{SH}$ intermediate reacts with another molecule of cysteine to give benzamide and cysteine perthiol, which finally reacts with cysteine to generate cystine and release $\mathrm{H}_{2} \mathrm{~S}$.

As cysteine perthiol was found to be the key intermediate for $\mathrm{H}_{2} \mathrm{~S}$ generation from Nmercapto-based donors, in addition to its already-known involvement in $\mathrm{H}_{2} \mathrm{~S}$ biosynthesis catalyzed by CSE [118,144], a library of perthiol-based donors (RC(O)-S-SR') were designed and developed by Zhao and co-workers [50], aiming to mimic $\mathrm{H}_{2} \mathrm{~S}$ bioproduction.

The authors prepared the above compounds as cysteine and penicillamine derivatives (Figure S14) and protected the unstable -SH residue with acyl groups.

Cys-S-SH-based donors were obtained through the treatment of N-benzoyl cysteine methyl ester with $2,2^{\prime}$-dipyridyl disulfide to attain a reactive intermediate, which then reacted with a thioacid to produce the desired compounds (Figure S15).

To obtain the other derivatives, $\mathrm{C}$ - and $\mathrm{N}$-protected penicillamine was treated with 2,2'-dibenzothioazolyldisulfide, furnishing an intermediate, which quickly reacted with different thioacids to produce the desired donors (Figure S16).

Surprisingly, it was found that these donors exhibit different $\mathrm{H}_{2} \mathrm{~S}$-releasing profiles. Indeed, in the presence of thiols, penicillamine-based donors showed higher efficiency in $\mathrm{H}_{2} \mathrm{~S}$ production than cysteine-based donors, which were able to release very small amounts of $\mathrm{H}_{2} \mathrm{~S}$. Probably, the two different behaviors could be explained by the presence of the two adjacent methyl groups of penicillamine-based donors, which prevent the cleavage of the disulfide bonds by thiols. 
These donors showed tunable release rates by varying the aromatic $\mathrm{R}$ substituent. $\mathrm{H}_{2} \mathrm{~S}$ release depends on both steric and electronic factors, with electron-withdrawing substituents accelerating release rates, and bulky substituents on the aromatic ring retarding release rates.

Regarding the $\mathrm{H}_{2} \mathrm{~S}$-releasing mechanism, the acyl perthiol donors also required disulfide exchange to allow $\mathrm{H}_{2} \mathrm{~S}$ production, similarly to N-mercapto-based donors; therefore, deacylation and subsequent $\mathrm{H}_{2} \mathrm{~S}$ release occurred (Figure 10).

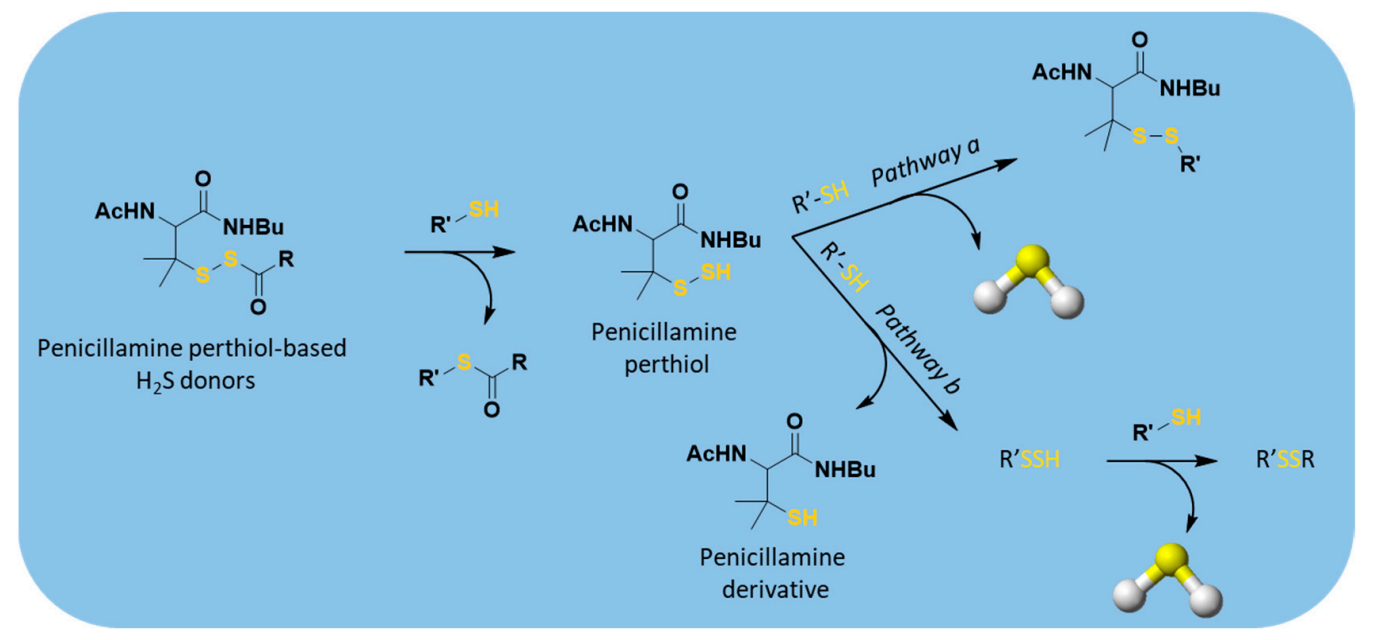

Figure 10. Proposed mechanism of $\mathrm{H}_{2} \mathrm{~S}$ release from perthiol-based donors; $\mathrm{R}^{\prime}-\mathrm{SH}=$ cysteine or GSH.

$\mathrm{H}_{2} \mathrm{~S}$ release from penicillamine-derived perthiol donors was also studied in vivo and in cardiac myocytes (H9c2 cells), confirming their ability to release. Moreover, the selected donors were evaluated into a murine model of myocardial I/R injury. The results proved that they exhibit cardioprotective activity due to their ability to reduce the infarct size.

Analogous perthiol-based donors are the dithioperoxyanhydrides $\left(\mathrm{RC}(\mathrm{O})-\mathrm{S}-\mathrm{SC}(\mathrm{O}) \mathrm{R}^{\prime}\right)$ [51], which also have the disulfide linkage in their structures (Figure S12).

Both alkyl and aromatic dithioperoxyanhydride donors were obtained by two possible synthetic strategies: iodine oxidation of the thiocarboxylates [145] or reactions between thiocarboxylic acids and methoxycarbonylsulfenyl chloride [146] (Figure S17).

$\mathrm{H}_{2} \mathrm{~S}$ release from these compounds was measured amperometrically and found in both buffers and cellular lysates, confirming $\mathrm{H}_{2} \mathrm{~S}$-releasing properties of dithioperoxyanhydrides. When treated with thiols, these donors formed a key intermediate for $\mathrm{H}_{2} \mathrm{~S}$ production, the acyl-persulfides, which, reacting with the excess of thiols, could directly release $\mathrm{H}_{2} \mathrm{~S}$ and RSSAc (pathway a, Figure 11); alternatively, it could produce a new perthiol species (RS-SH), which reacting in turn with thiols, leads to disulfide formation and $\mathrm{H}_{2} \mathrm{~S}$ release (pathway b, Figure 11).

Furthermore, these donors were found to induce concentration-dependent vasorelaxation of pre-contracted rat aortic rings, presumably owing to $\mathrm{H}_{2} \mathrm{~S}$ release. Moreover, the arylthioamides (Figure S12) were also classified as thiol-activated $\mathrm{H}_{2} \mathrm{~S}$ donors [52]. The non-heterocyclic aromatic compounds were obtained by mixing the corresponding benzonitrile with $\mathrm{P}_{4} \mathrm{~S}_{10}$; whereas the reaction between amides with Lawesson's reagent led to heterocyclic aromatic compounds being obtained (Figure S18).

These compounds showed the ability to release $\mathrm{H}_{2} \mathrm{~S}$ in the presence of thiols, similarly to DADS and GYY4137, two slow-releasing donors. To date, the $\mathrm{H}_{2} \mathrm{~S}$ release mechanism and relative intermediates and final products have not yet been clearly described. 


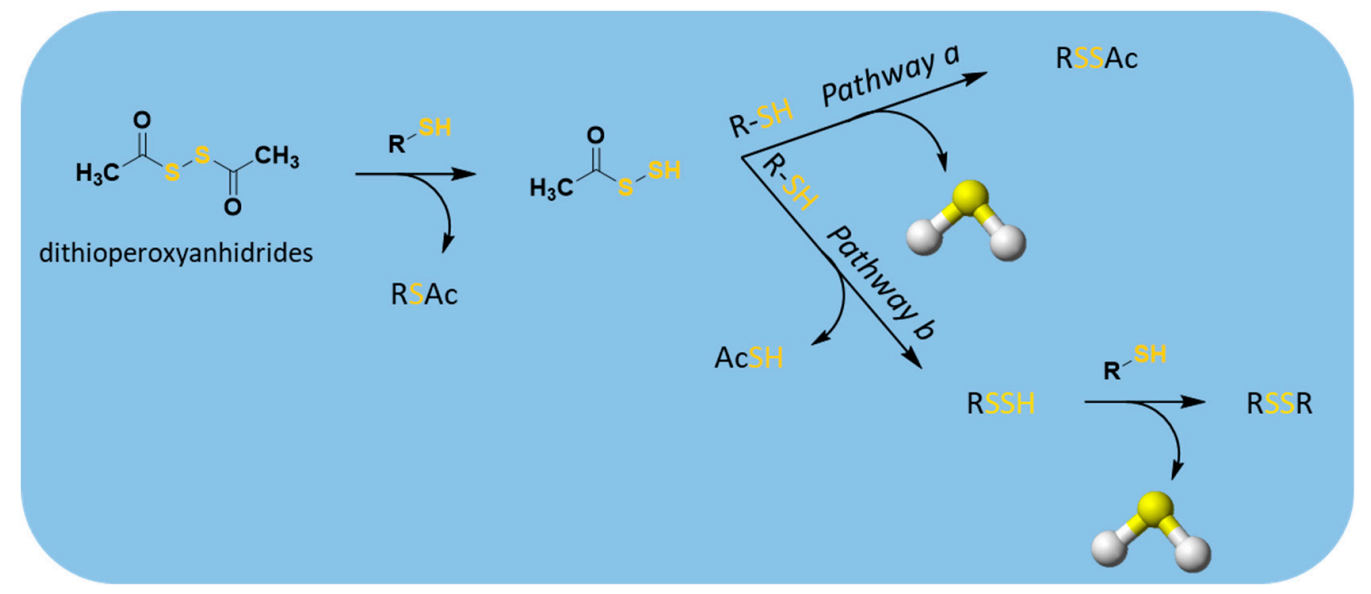

Figure 11. Proposed mechanism for $\mathrm{H}_{2} \mathrm{~S}$ release from dithioperoxyanhydrides; $\mathrm{R}^{\prime}-\mathrm{SH}=$ cysteine or GSH.

After confirming their $\mathrm{H}_{2} \mathrm{~S}$-releasing profile, Calderone and coworkers tested the effects of these donors on noradrenaline-induced vasoconstriction in isolated rat aortic rings. The results suggested that the lead compound, $p$-hydroxybenzothioamide (Figure S19), has protective activity in cardiovascular systems, inhibiting norepinephrine-induced vasoconstriction in ex vivo in rat aortic rings, and reducing systolic blood pressure.

Considering the slow and sustained $\mathrm{H}_{2} \mathrm{~S}$ release profile of $p$-hydroxybenzothioamide and its ease of conjugation to other compounds, this donor was used to develop many hybrid compounds. Among these, $p$-hydroxybenzothioamide was conjugated with the active compound naproxen, obtaining ATB-346 (Figure S19) [147]. Thus, the efficacy of this hybrid as an anticancer drug was investigated, confirming its apoptotic action in human melanoma cells [148]. Moreover, it has been demonstrated that ATB-346 reduces gastrointestinal tract injury and exhibits chemopreventive action against colorectal cancer when compared to naproxen [149]. Recently, a phase II study was completed and revealed that ATB-346 is useful for the treatment of pain associated with osteoarthritis [150].

These positive preclinical data for ATB-346 suggested that $\mathrm{H}_{2} \mathrm{~S}$-releasing hybrid drugs could undergo further development for the treatment of cardiovascular disease.

Moreover, Martelli and co-workers reported aryl isothiocyanates as another series of thiol-activated $\mathrm{H}_{2} \mathrm{~S}$ donors (Figure S12) [57]. These compounds showed vasorelaxant effects on conductance and coronary arteries.

Noteworthy, 4-carboxyphenyl-isothiocyanate (4-CPI) and 3-pyridyl-isothiocyanate (Figure S20) exhibited cardioprotective effects against I/R injury, reducing myocardial contractility, ventricular arrhythmias, and oxidative stress [58,151].

The mechanism of $\mathrm{H}_{2} \mathrm{~S}$ release from these compounds has already been described above (Figure 6). The nature of the $\mathrm{R}$ groups supporting the isothiocyanate function have a strong impact on $\mathrm{H}_{2} \mathrm{~S}$-releasing rates. For examples, $p$-nitrophenyl isothiocyanate produces $\mathrm{H}_{2} \mathrm{~S}$ relatively fast, while benzylisothiocyanate and phenethyl isothiocyanate are considered slow $\mathrm{H}_{2} \mathrm{~S}$ donors [101].

More recently, 1,2,4-thiadiazolidine-3,5-diones (THIA) (Figure S12), which are isothiocyanate derivatives, developed by Severino et al. [53], were demonstrated to be novel thiol-triggered $\mathrm{H}_{2} \mathrm{~S}$ donors.

These compounds were obtained through oxidative condensation of isothiocyanates with isocyanates in the presence of $\mathrm{SO}_{2} \mathrm{Cl}_{2}$, using both the conventional synthetic strategy, previously described in literature [152], and the microwave-assisted synthesis [53]. The second way led better yields being obtained and the reduction of reaction times (Figure S21). The authors clearly defined the mechanism of $\mathrm{H}_{2} \mathrm{~S}$ release by using a combination of HPLC, MS, and NMR to isolate and characterize the intermediates and the final products. 
As depicted in Figure 12, the nucleophilic attack of thiols, for example cysteine, on the electron deficient sulfur atom of the 1,2,4-thiadiazolidine-3,5-dione nucleus opens the ring and produces an intermediate. When this latter reacts with a second molecule of cysteine, it generates cystine and phenyl(phenylcarbamoyl)carbamothioic S-acid, an instable intermediate, which is immediately hydrolyzed, yielding 1,3-diphenylurea, $\mathrm{CO}_{2}$, and $\mathrm{H}_{2} \mathrm{~S}$.

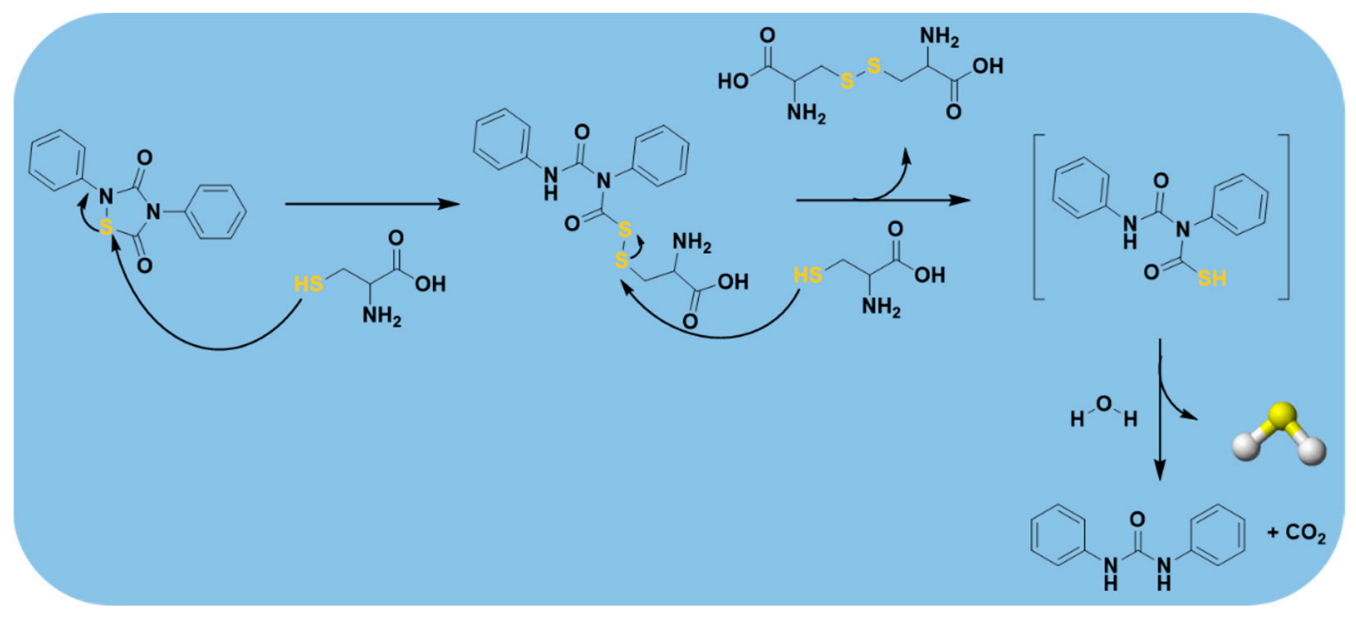

Figure 12. $\mathrm{H}_{2} \mathrm{~S}$-releasing mechanism from 1,2,4-thiadiazolidine-3,5-diones (THIA).

It was also found that these donors exerted vasodilating activity in a concentrationdependent manner on isolated aorta rings.

Furthermore, a sodium polysulthionate, named SG-1002 (Figure S12), was developed. This synthetic $\mathrm{H}_{2} \mathrm{~S}$ prodrug is a water-insoluble microcrystalline material, mostly consisting of $\alpha$-sulfur (about $99 \% \mathrm{~S}_{8}$ ) hydrophilized with traces of ionic substances, such as sodium sulfate, sodium thiosulfate, and sodium polythionates, which enhance its bioavailability [153].

SG-1002 was obtained via comproportionation of sulfur atoms in the -2 and +4 oxidation states in a strongly acidic medium of high ionic strength. This synthetic route, together with properties and some therapeutic applications of SG1002 are described in a patent [154]. $\mathrm{H}_{2}$ S-releasing from $\mathrm{S}_{8}$ is activated by thiols and this reaction with GSH is depicted in Figure S22 [155-157].

SG-1002, when administered orally, produced a more sustained and consistent increase in $\mathrm{H}_{2} \mathrm{~S}$ and sulfane sulfur levels in models of pressure overload heart failure. Moreover, it improved coronary artery vascular reactivity and attenuated high-fat diet-induced cardiac hypertrophy and dysfunction $[153,158,159]$.

Importantly, SG-1002 has completed the phase I clinical trial where its $\mathrm{H}_{2} \mathrm{~S}$-donating ability in patients with congestive heart failure was investigated [160]. The results of this trial confirmed that SG-1002 is useful both in healthy patients and in patients with heart failure. Indeed, it effectively enhances sulfide and NO levels in patients with heart failure. Nevertheless, further trials are required to test the drug's efficacy [161].

To date, it is the only sulfide-based therapy clinically tested in patients with cardiovascular diseases.

\subsubsection{Enzyme-Triggered Donors}

In recent years, enzyme-triggered $\mathrm{H}_{2} \mathrm{~S}$ donors have been received increasing interest due to their many advantages over the other triggers already mentioned above. Among these, a series of esterase-sensitive prodrugs of $\mathrm{H}_{2} \mathrm{~S}$, based on a lactonization reaction, also known as "trimethyl lock" (TML) [162], was developed by Zheng et al. [163] (Figure S23). 
The first synthesized derivative, HP-101, was obtained starting from compound 1 (Figure S24), which, reacting with Lawesson's reagent under microwave conditions [164], resulted in an intermediate that was then treated with one equivalent of sodium hydroxide.

The obtained TML-based prodrugs were able to release $\mathrm{H}_{2} \mathrm{~S}$, through the cleavage of a phenolic ester by an esterase and subsequent lactonization, owing to the steric repulsion of three methyl groups (Figure 13).

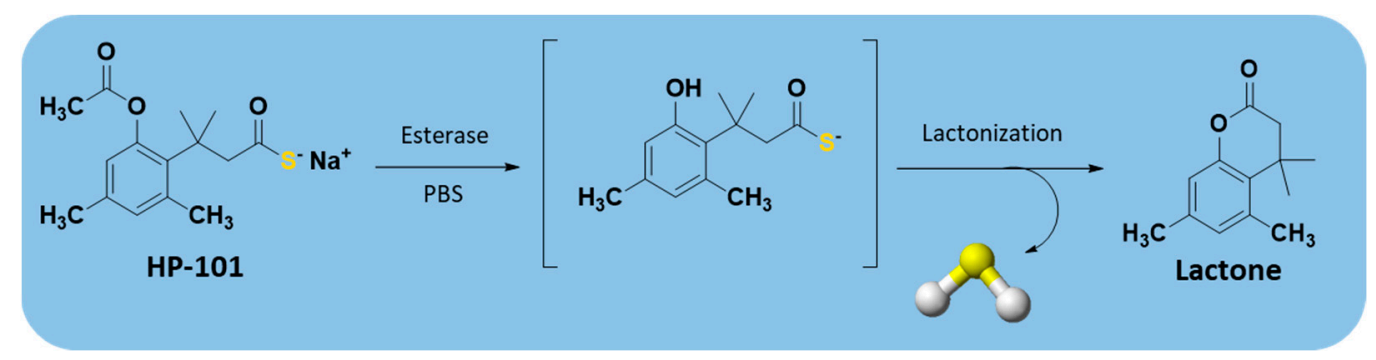

Figure 13. Mechanism of esterase-triggered $\mathrm{H}_{2} \mathrm{~S}$ release.

Interestingly, a TML derivative, HP-102 (Figure S24), was found to attenuate myocardial I/R injury in a dose-dependent manner and exhibited a cardioprotective action [165]. Thus, this compound is currently under investigation to better define its chemical, pharmacological, and safety profile in the hope that it could be tested in clinical trials.

Another class of enzyme-triggered $\mathrm{H}_{2} \mathrm{~S}$ donors is carbonyl sulfide (COS)-releasing compounds. Indeed, COS is a substrate of carbonic anhydrase (CA), which catalyzes its conversion into $\mathrm{H}_{2} \mathrm{~S}[166,167]$.

An example of these dual $\mathrm{COS} / \mathrm{H}_{2} \mathrm{~S}$ donors are $\mathrm{N}$-thiocarboxyanhydrides (NTAs) (Figure S25) [168,169], which have the advantage of releasing, in addition to COS, only innocuous peptide byproducts [170].

The sarcosine NTA derivative (NTA1) (Figure S25) was synthesized starting from sarcosine (N-methyl glycine) through the route depicted in Figure S26 [171].

The mechanism leading to $\mathrm{H}_{2} \mathrm{~S}$ production from NTA1 consists of ring-opening by a biological nucleophile, such as an amine. The resulting dipeptide byproducts were confirmed by GC-MS and LC-MS, respectively. After COS release, its conversion into $\mathrm{H}_{2} \mathrm{~S}$ occurs through the rapid enzymatic action of CA (Figure 14) [170].

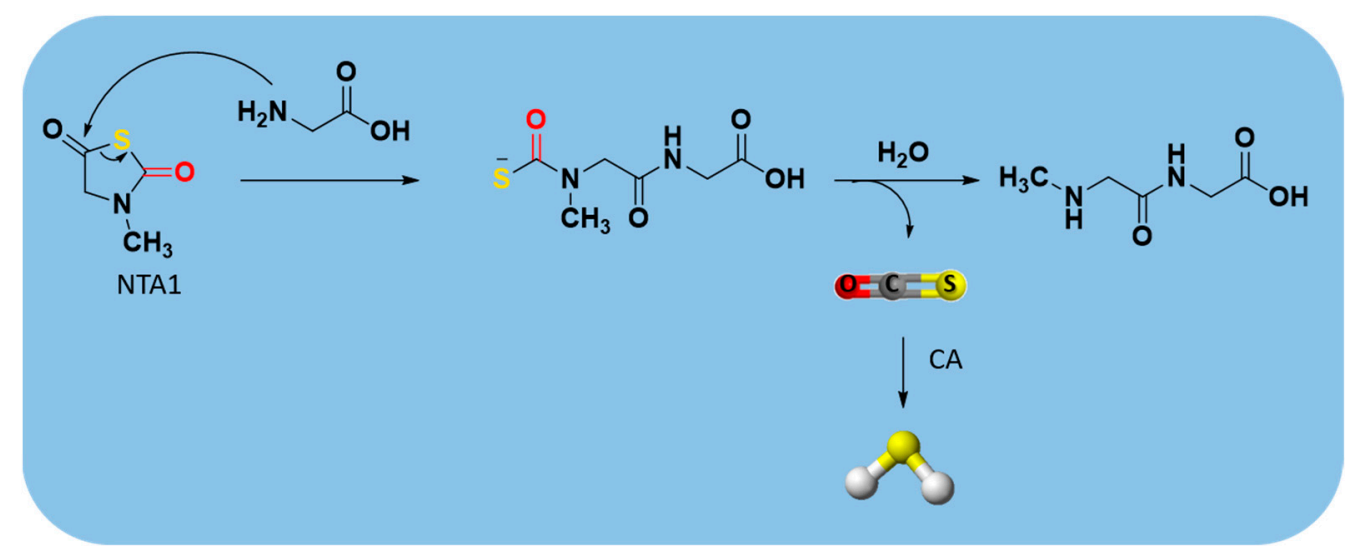

Figure 14. Mechanism of carbonyl sulfide (COS) $/ \mathrm{H}_{2} \mathrm{~S}$ release from NTA1.

Furthermore, Powell et al. showed that the treatment of endothelial cells with NTA1 increased proliferation, which is an important step in the angiogenetic process [170]. 
Among the class of $\mathrm{COS} / \mathrm{H}_{2} \mathrm{~S}$ donors, some ROS-triggered $\mathrm{H}_{2} \mathrm{~S}$ donors (peroxyTCM$1,2,3)$ were developed [172], using a ROS-cleavable aryl boronate as the protecting group $[173,174]$. They were obtained as depicted in Figure S27.

The obtained compounds were found to release $\mathrm{H}_{2} \mathrm{~S}$ in the presence of an oxidant, such as $\mathrm{H}_{2} \mathrm{O}_{2}$. In this mechanism, the boronate ester was converted to a phenol by ROS, releasing $\mathrm{COS}$, which was quickly converted into $\mathrm{H}_{2} \mathrm{~S}$ by CA [172] (Figure 15).

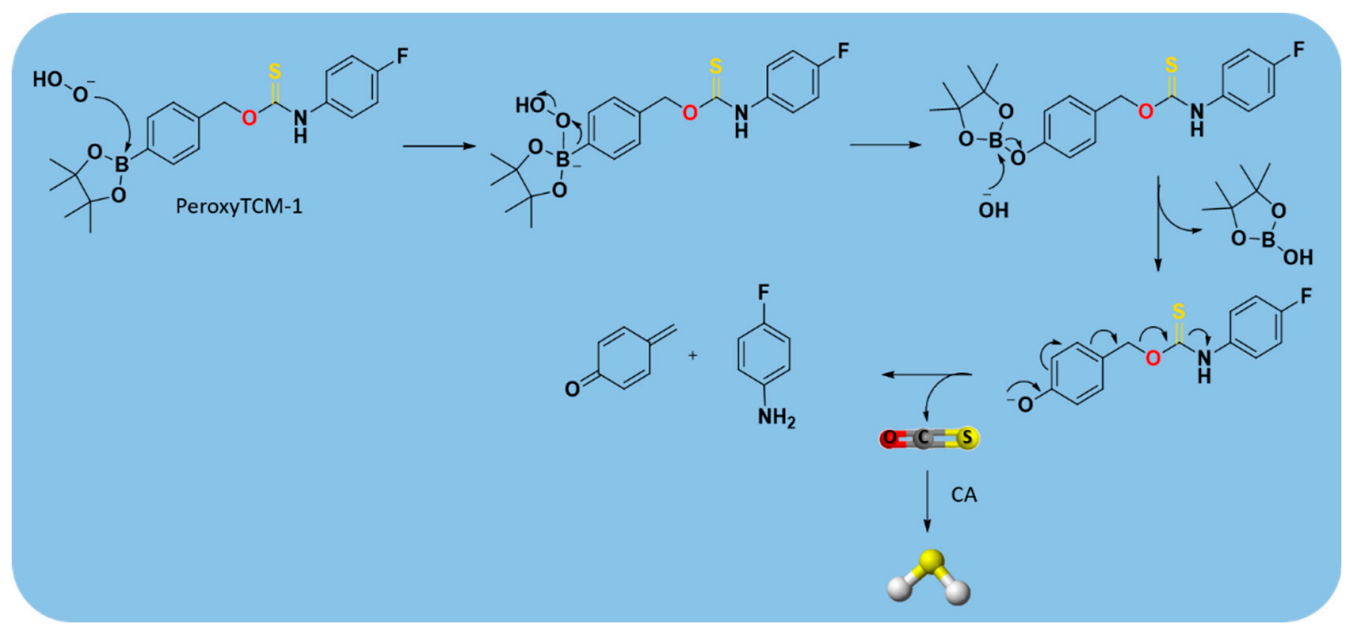

Figure 15. Proposed mechanism for $\mathrm{H}_{2} \mathrm{O}_{2}$-triggered COS $/ \mathrm{H}_{2} \mathrm{~S}$ release.

Moreover, it was demonstrated that the combined role of boronate ester, as ROS scavenger, with the produced $\mathrm{H}_{2} \mathrm{~S}$, as cytoprotective agent, led the ROS-activated $\mathrm{H}_{2} \mathrm{~S}$ donors to exhibit important activities in many human pathologies driven by high oxidative stress, such as cardiovascular diseases [133].

However, further in vivo studies are required to better characterize the biological nature of these donors and to confirm their efficacy.

\subsubsection{Others}

In 2012, Zhou et al. reported that thioamino acids, such as thioglycine and thiovaline, were bicarbonate-triggered $\mathrm{H}_{2} \mathrm{~S}$ donors [48]. They synthesized the selected compounds starting from commercially available Boc-protected amino acids, which were treated with $1,1^{\prime}$-carbonyldiimidazole in dichloromethane and subsequently with gaseous $\mathrm{H}_{2} \mathrm{~S}$. The following deprotection with trifluoroacetic acid (TFA) in dichloromethane furnished the desired compounds (Figure S28).

The authors proved that, in the presence of bicarbonate, these compounds react through their amine groups and consequently undergo a cyclization, converting to the corresponding amino acid N-carboxyanhydrides with the production of $\mathrm{H}_{2} \mathrm{~S}$ (Figure 16). Considering the proposed mechanism of release and the high concentrations of bicarbonate in blood, thioamino acids could be effective $\mathrm{H}_{2} \mathrm{~S}$ donors.

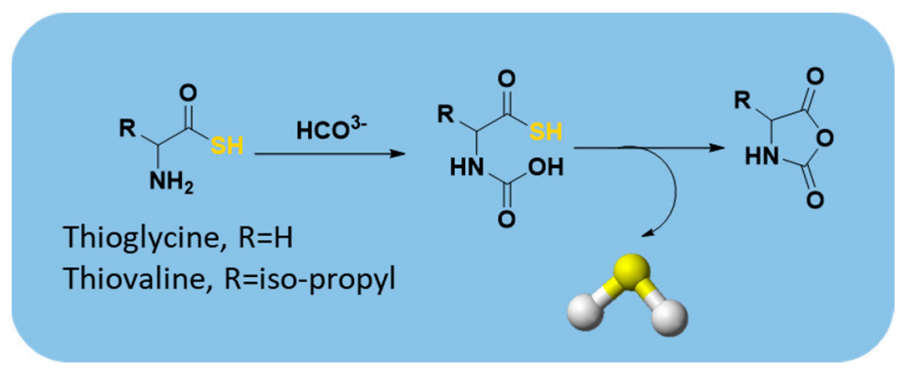

Figure 16. Proposed mechanism for $\mathrm{H}_{2} \mathrm{~S}$ release from thioamino acids. 
Indeed, $\mathrm{H}_{2} \mathrm{~S}$-releasing capabilities of thioglycine and thiovaline were evaluated and proved amperometrically. In addition, both thioglycine and thiovaline were found to enhance cGMP formation in a concentration-dependent manner and induce significant relaxation of pre-contracted mouse aortic rings.

However, the high reactivity of these amino acids must be considered. In fact, it was found that under aerobic conditions they could rapidly undergo amidation [175-180] and oxidation reactions [51], yielding products which could lead to unwanted side effects.

Recently, a novel $\mathrm{H}_{2} \mathrm{~S}-\mathrm{NO}$-releasing molecule, 2-(N-Boc-amino)-3-prop-2-ynylsulfanylpropionic acid, named ZYZ803, was developed [181] by coupling SPRC with furoxan, upon treatment with Boc anhydride (Figure S29) [181,182].

As already described above, SPRC could enhance $\mathrm{H}_{2} \mathrm{~S}$ concentration in plasma through the activation of CSE enzyme [92] while furoxan is a thiol-triggered NO-releasing compound [183].

Therefore, ZYZ803 stimulated both the expression of CSE and the activity of endothelial NO synthase (e-NOS), releasing $\mathrm{H}_{2} \mathrm{~S}$ and NO, respectively (Figure 17). These gasotransmitters promoted angiogenesis through the SIRT1/VEGF/cGMP pathway and via cross-talk between STAT3 and CaMKII [184].

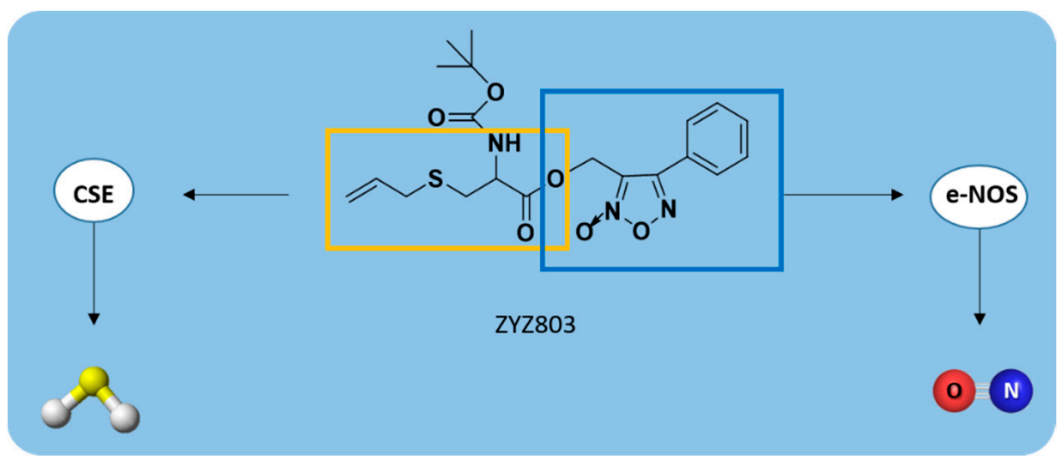

Figure 17. $\mathrm{H}_{2} \mathrm{~S} / \mathrm{NO}$-releasing mechanism from ZYZ803.

As reported by Hu et al., ZYZ803 significantly promoted endothelial cell angiogenesis both in vitro and in vivo [185].

Indeed, the oral administration of ZYZ803 in a mouse model of hindlimb ischemia stimulated angiogenesis more effectively than individually administered SPRC and furoxan, confirming the additive protective actions of $\mathrm{H}_{2} \mathrm{~S}$ and $\mathrm{NO}$ releasing from ZYZ803 [185].

Additionally, ZYZ803 regulated the vascular tone in isolated rat aortic rings [181], attenuated cardiac dysfunction, and improved myocardial injury after heart failure [186], exerting a powerful cardioprotective effect.

Lastly, another $\mathrm{H}_{2} \mathrm{~S}$ donor with activity in the cardiovascular system is zofenopril, an angiotensin-converting enzyme (ACE) inhibitor. Undergoing hydrolysis in the liver, it forms zofenoprilat, its active metabolite containing a thiol group (Figure S30).

It is important to underline that zofenopril is not a new drug; in fact, it was approved for medical use in 2000. Recently, Bucci et al. demonstrated that this compound can release $\mathrm{H}_{2} \mathrm{~S}$ [187], which mediates the beneficial effects of zofenopril, such as anti-inflammatory, pro-angiogenic and anti-apoptotic activity [187-191].

Additionally, zofenopril was reported to improve vascular function in a model of hypertension, combining its ACE inhibitor activity and $\mathrm{H}_{2} \mathrm{~S}$-releasing properties [187].

Indeed, it was also found that zofenopril administration increases the levels of $\mathrm{H}_{2} \mathrm{~S}$ metabolites in the plasma of mice, protecting against myocardial I/R injury, and pigs, improving endocardial blood flow in myocardial ischemia [192]. 


\section{Conclusions}

During last decades, remarkable progress has been made in the understanding of the biological activity of $\mathrm{H}_{2} \mathrm{~S}$ and its mechanism of actions in the cardiovascular system and in the discovering and developing of novel $\mathrm{H}_{2} \mathrm{~S}$-releasing compounds.

Herein we presented an overview of the currently available $\mathrm{H}_{2} \mathrm{~S}$ donating agents that have been tested in preclinical models of cardiovascular diseases, with a focus on fundamental chemistry and their $\mathrm{H}_{2} \mathrm{~S}$-releasing properties and mechanisms.

As described above, these $\mathrm{H}_{2} \mathrm{~S}$ donors include inorganic sulfide salts, natural and synthetic organic compounds, characterized by different release triggering mechanisms.

Although many donors have been developed and tested in vitro and in vivo studies, showing their ability to release $\mathrm{H}_{2} \mathrm{~S}$ and the positive effects when treating cardiovascular diseases, to date it is not yet possible to identify an ideal donor, owing to some drawbacks for each of them.

Indeed, the major limitations for many donors are that the release does not mimic the endogenous $\mathrm{H}_{2} \mathrm{~S}$ production and leads to the simultaneous generation of reactive byproducts, whose nature and biological activity are often still unknown.

To overcome these drawbacks, several new classes of donors with a sustained and controlled $\mathrm{H}_{2} \mathrm{~S}$ release were designed, synthesized, and studied for their biological activity, also defining their mechanism of release; moreover, they were successfully tested in various animal models of cardiovascular disease.

Among them, at least two $\mathrm{H}_{2} \mathrm{~S}$-releasing compounds (ATTM and SG-1002) have completed the phase I clinical trials and registered on clinicaltrials.gov for cardiovascular disease and breast cancer (Table 1).

Nevertheless, there are still too few available donors with oral bioavailability, which is crucial for clinical translation, and being available for testing in in vivo pharmacokinetic studies. Furthermore, the safety and long-term effects of many $\mathrm{H}_{2} \mathrm{~S}$-releasing compounds have yet to be more tested and fully characterized.

Bearing in mind the above considerations, this work, by reviewing the available $\mathrm{H}_{2} \mathrm{~S}$ donors exhibiting cardioprotective activity and thus providing an insightful knowledge of their chemical nature and mechanisms of release, could enhance the chances to design novel $\mathrm{H}_{2} \mathrm{~S}$-donating molecules useful to help further reduce the risks of cardiovascular disease in the coming years.

Supplementary Materials: The following are available online at https:/ /www.mdpi.com/2076-3 921/10/3/429/s1, The following are available online. Figure S1. The chemical structures of SAC, SPC, and SPRC. Figure S2. Chemical structures of hydrolysis-triggered $\mathrm{H}_{2} \mathrm{~S}$ donors. Figure S3. Chemical synthesis of GYY4137. Figure S4. The hydrolytic degradation of GYY4137 and the $\mathrm{H}_{2} \mathrm{~S}$ release. Figure S5. Structures of the most used DTTs as $\mathrm{H}_{2} \mathrm{~S}$ donors. Figure S6. Different chemical strategies to synthesize DTTs. Figure S7. Mechanism of $\mathrm{H}_{2} \mathrm{~S}$ release from DTTs. Figure S8. Chemical synthesis of HS-NSAIDs. Figure S9. Synthetic strategy to obtain JK donors. Figure S10. Chemical structures of two main JK donors. Figure S11. The $\mathrm{H}_{2} \mathrm{~S}$ release from ammonium tetrathiomolybdate (ATTM). Figure S12. Chemical structures of thiol-triggered $\mathrm{H}_{2} \mathrm{~S}$ donors with cardioprotective activity. Figure S13. Chemical synthesis of N-(benzoylthio)benzamides. Figure S14. Chemical structures of perthiol-based donors. Figure S15. Synthetic route to obtain cysteine perthiol-based donors. Figure S16. Chemical synthesis of penicillamine perthiol-based donors. Figure S17. The synthetic strategies to obtain dithioperoxyanhydride-based $\mathrm{H}_{2} \mathrm{~S}$. Figure S18. Chemical synthesis of (a) non-heterocyclic and (b) heterocyclic p-hydroxy-arylthio-amides. Figure S19. The thioamides: General structure, chemical structures of lead compound (p-hydroxybenzothioamide) and its hybrid with naproxen (ATB-346). Figure S20. Chemical structures of two aryl isothiocyanates exhibiting cardioprotective activity. Figure S21. Synthesis of THIA. Conventional synthetic strategy: (i) $\mathrm{SO}_{2} \mathrm{Cl}_{2} /$ diethyl ether, 24 h; (ii) $\mathrm{H}_{2} \mathrm{O}$, reflux, $30 \mathrm{~min}$; microwave-assisted synthesis: (i) $\mathrm{SO}_{2} \mathrm{Cl}_{2}$ /diethyl ether/MW $500 \mathrm{~W}, 50^{\circ} \mathrm{C}$, 1h; (ii) $\mathrm{H}_{2} \mathrm{O}$, MW $500 \mathrm{~W}, 120^{\circ} \mathrm{C}, 30 \mathrm{~min}$. Figure S22. Mechanism of $\mathrm{H}_{2} \mathrm{~S}$ release from SG1002. Figure S23. Chemical structures of "TML"-based $\mathrm{H}_{2} \mathrm{~S}$ prodrugs HP-101 and HP-102. Figure S24. Synthesis of "TML"-based $\mathrm{H}_{2} \mathrm{~S}$ prodrug HP-101. Figure S25. Chemical structures of N-thiocarboxyanhydrides (NTAs) and sarcosine NTA derivative (NTA1). Figure S26. Chemical synthesis of sarcosine NTA 
derivative (NTA1). Figure S27. Chemical structures and synthesis of ROS-activated $\mathrm{H}_{2} \mathrm{~S}$ donors. Figure S28. Synthesis of thioamino acids. Figure S29. Chemical structure and synthesis of ZYZ803. Figure S30. Chemical structures of (a) zofenopril and (b) its active metabolite, zofenoprilat.

Author Contributions: Conceptualization, A.C., G.C. and V.S.; resources, F.F. (Francesco Frecentese) and A.S.; writing-original draft preparation, A.C., B.S., E.M. and E.P.; writing-review and editing, B.S. and F.F. (Ferdinando Fiorino); supervision, B.S. and F.F. (Ferdinando Fiorino). All authors have read and agreed to the published version of the manuscript.

Funding: This research received no external funding.

Conflicts of Interest: The authors declare no conflict of interest.

\section{References}

1. Wang, R. Two's Company, Three's a Crowd: Can $\mathrm{H}_{2}$ S Be the Third Endogenous Gaseous Transmitter? FASEB J. 2002, 16, 1792-1798. [CrossRef]

2. Ungerer, P.; Wender, A.; Demoulin, G.; Bourasseau, É.; Mougin, P. Application of Gibbs Ensemble and NPT Monte Carlo Sim-Ulation to the Development of Improved Processes for $\mathrm{H}_{2} \mathrm{~S}-$ Rich Gases. Mol. Simul. 2004, 30, 631-648. [CrossRef]

3. Kabil, O.; Banerjee, R. Redox Biochemistry of Hydrogen Sulfide. J. Biol. Chem. 2010, 285, 21903-21907. [CrossRef] [PubMed]

4. Li, L.; Rose, P.; Moore, P.K. Hydrogen Sulfide and Cell Signaling. Annu. Rev. Pharmacol. Toxicol. 2011, 51, 169-187. [CrossRef]

5. Gadalla, M.M.; Snyder, S.H. Hydrogen Sulfide as a Gasotransmitter. J. Neurochem. 2010, 113, 14-26. [CrossRef]

6. Miles, E.W.; Kraus, J.P. Cystathionine $\beta$-Synthase: Structure, Function, Regulation, and Location of Homocystinuria-causing Mutations. J. Biol. Chem. 2004, 279, 29871-29874. [CrossRef]

7. Pan, L.L.; Liu, X.H.; Gong, Q.H.; Yang, H.B.; Zhu, Y.Z. Role of Cystathionine C-Lyase/Hydrogen Sulfide Pathway in CardioVascular Disease: A Novel Therapeutic Strategy? Antioxid. Redox Signal. 2011, 17, 106-118. [CrossRef]

8. Shibuya, N.; Tanaka, M.; Yoshida, M.; Ogasawara, Y.; Togawa, T.; Ishii, K.; Kimura, H. 3-Mercaptopyruvate Sulfurtransferase Produces Hydrogen Sulfide and Bound Sulfane Sulfur in the Brain. Antioxidants Redox Signal. 2009, 11, 703-714. [CrossRef]

9. Marcotte, P.; Walsh, C. Active Site-Directed Inactivation of Cystathionine Gamma-Synthetase and Glutamic Pyruvic TransamiNase by Propargylglycine. Biochem. Biophys. Res. Commun. 1975, 62, 677-682. [CrossRef]

10. Sun, Q.; Collins, R.; Huang, S.; Holmberg-Schiavone, L.; Anand, G.S.; Tan, C.H.; van-den-Berg, S.; Deng, L.W.; Moore, P.K.; Karlberg, T.; et al. Structural Basis for the Inhibition Mechanism of Human Cystathionine Gamma-Lyase, an Enzyme Responsible for the Production of $\mathrm{H}_{2}$ S. J. Biol. Chem. 2009, 284, 3076-3085. [CrossRef]

11. Pfeffer, M.; Ressler, C. $\beta$-Cyanoalanine, An Inhibitor of Rat Liver Cystathionase. Biochem. Pharmacol. 1967, 16, $2299-2308$. [CrossRef]

12. Corvino, A.; Severino, B.; Fiorino, F.; Frecentese, F.; Magli, E.; Perissutti, E.; Santagada, V.; Bucci, M.; Cirino, G.; Kelly, G.; et al. Fragment-Based de Novo Design of a Cystathionine $\gamma$-Lyase Selective Inhibitor Blocking Hydrogen Sulfide Production. Sci. Rep. 2016, 6, srep34398. [CrossRef]

13. Asimakopoulou, A.; Panopoulos, P.; Chasapis, C.T.; Coletta, C.; Zhou, Z.; Cirino, G.; Giannis, A.; Szabo, C.; Spyroulias, G.A.; Papapetropoulos, A. Selectivity of Commonly Used Pharmacological Inhibitors for Cystathionine $\beta$ Synthase (CBS) and Cystathi-Onine $\gamma$ Lyase (CSE). Br. J. Pharm. 2013, 169, 922-932. [CrossRef]

14. Moore, P.K.; Bhatia, M.; Moochhala, S. Hydrogen Sulfide: From the Smell of the past to the Mediator of the Future? Trends Pharmacol. Sci. 2003, 24, 609-611. [CrossRef]

15. Wang, R. Hydrogen Sulfide: The Third Gasotransmitter in Biology and Medicine. Antioxid. Redox Signal. 2010, 12, 1061-1064. [CrossRef]

16. Polhemus, D.J.; Lefer, D.J. Emergence of Hydrogen Sulfide as an Endogenous Gaseous Signaling Molecule in Cardiovascular Disease. Circ. Res. 2014, 114, 730-737. [CrossRef]

17. Huang, S.; Li, H.; Ge, J. A Cardioprotective Insight of the Cystathionine $\gamma$-Lyase/Hydrogen Sulfide Pathway. IJC Hear. Vasc. 2015, 7, 51-57. [CrossRef]

18. Meng, G.; Ma, Y.; Xie, L.; Ferro, A.; Ji, Y. Emerging Role of Hydrogen Sulfide in Hypertension and Related Cardiovascular Diseases. Br. J. Pharmacol. 2015, 172, 5501-5511. [CrossRef]

19. Wang, X.-H.; Wang, F.; You, S.-J.; Cao, Y.-J.; Cao, L.-D.; Han, Q.; Liu, C.-F.; Hu, L.-F. Dysregulation of Cystathionine $\gamma$-Lyase (CSE)/Hydrogen Sulfide Pathway Contributes to Ox-LDL-Induced Inflammation in Macrophage. Cell. Signal. 2013, 25, $2255-2262$. [CrossRef]

20. Whiteman, M.; Moore, P.K. Hydrogen Sulfide and the Vasculature: A Novel Vasculoprotective Entity and Regulator of Nitric Oxide Bioavailability? J. Cell. Mol. Med. 2009, 13, 488-507. [CrossRef]

21. Xu, Y.; Du, H.-P.; Li, J.; Xu, R.; Wang, Y.-L.; You, S.-J.; Liu, H.; Wang, F.; Cao, Y.-J.; Liu, C.-F.; et al. Statins Upregulate Cystathionine $\gamma$-Lyase Transcription and $\mathrm{H}_{2} \mathrm{~S}$ Generation via Activating Akt Signaling in Macrophage. Pharmacol. Res. 2014, 87, 18-25. [CrossRef] [PubMed]

22. Yu, X.-H.; Cui, L.-B.; Wu, K.; Zheng, X.-L.; Cayabyab, F.S.; Chen, Z.-W.; Tang, C.-K. Hydrogen Sulfide as a Potent Cardiovascular Protective Agent. Clin. Chim. Acta 2014, 437, 78-87. [CrossRef] 
23. Zheng, Y.; Ji, X.; Ji, K.; Wang, B. Hydrogen Sulfide Prodrugs-A Review. Acta Pharm. Sin. B 2015, 5, 367-377. [CrossRef] [PubMed]

24. Calvert, J.W.; Elston, M.; Nicholson, C.K.; Gundewar, S.; Jha, S.; Elrod, J.W.; Ramachandran, A.; Lefer, D.J. Genetic and Pharmacologic Hydrogen Sulfide Therapy Attenuates Ischemia-Induced Heart Failure in Mice. Circulation 2010, 122, 11-19. [CrossRef]

25. Yang, G.; Wu, L.; Jiang, B.; Yang, W.; Qi, J.; Cao, K.; Meng, Q.; Mustafa, A.K.; Mu, W.; Zhang, S.; et al. H ${ }_{2} \mathrm{~S}$ as a Physiologic Vasorelaxant: Hypertension in Mice with Deletion of Cystathionine Gamma-Lyase. Science 2008, 322, 587-590. [CrossRef] [PubMed]

26. Wang, Y.; Zhao, X.; Jin, H.; Wei, H.; Li, W.; Bu, D.; Tang, X.; Ren, Y.; Tang, C.; Du, J. Role of Hydrogen Sulfide in the Devel-Opment of Atherosclerotic Lesions in Apolipoprotein E Knockout Mice. Arterioscler. Thromb. Vasc. Biol. 2009, 29, 173-179. [CrossRef]

27. Van Den Born, J.C.; Mencke, R.; Conroy, S.; Zeebregts, C.J.; Van Goor, H.; Hillebrands, J.L. Cystathionine Gamma-Lyase Is Expressed in Human Atherosclerotic Plaque Microvessels and Is Involved in Micro-Angiogenesis. Sci. Rep. 2016, 6, 1-13. [CrossRef] [PubMed]

28. Zhao, W.; Zhang, J.; Lu, Y.; Wang, R. The Vasorelaxant Effect of $\mathrm{H}_{2} \mathrm{~S}$ as a Novel Endogenous Gaseous KATP Channel Opener. EMBO J. 2001, 20, 6008-6016. [CrossRef] [PubMed]

29. Dawe, G.S.; Han, S.P.; Bian, J.S.; Moore, P.K. Hydrogen Sulphide in the Hypothalamus Causes an ATP-Sensitive K Chan-NelDependent Decrease in Blood Pressure in Freely Moving Rats. Neuroscience 2008, 152, 169-177. [CrossRef]

30. Liu, W.Q.; Chai, C.; Li, X.Y.; Yuan, W.J.; Wang, W.Z.; Lu, Y. The Cardiovascular Effects of Central Hydrogen Sulfide Are Related to K(ATP) Channels Activation. Physiol. Res. 2011, 60, 729-738. [CrossRef]

31. Wang, R. Physiological Implications of Hydrogen Sulfide: A Whiff Exploration That Blossomed. Physiol. Rev. 2012, 92, 791-896. [CrossRef]

32. Xu, S.; Liu, Z.; Liu, P. Targeting Hydrogen Sulfide as a Promising Therapeutic Strategy for Atherosclerosis. Int. J. Cardiol. 2014, 172, 313-317. [CrossRef]

33. Wang, R.; Szabo, C.; Ichinose, F.; Ahmed, A.; Whiteman, M.; Papapetropoulos, A. The Role of $\mathrm{H}_{2} \mathrm{~S}$ Bioavailability in Endothelial Dysfunction. Trends Pharmacol. Sci. 2015, 36, 568-578. [CrossRef] [PubMed]

34. Yuan, S.; Shen, X.; Kevil, C.G. Beyond a Gasotransmitter: Hydrogen Sulfide and Polysulfide in Cardiovascular Health and Im-Mune Response. Antioxid. Redox Signal. 2017, 27, 634-653. [CrossRef] [PubMed]

35. Hosoki, R.; Matsuki, N.; Kimura, H. The Possible Role of Hydrogen Sulfide as an Endogenous Smooth Muscle Relaxant in Synergy with Nitric Oxide. Biochem. Biophys. Res. Commun. 1997, 237, 527-531. [CrossRef] [PubMed]

36. Sanchez Aranguren, L.C.; Ahmad, S.; Dias, I.H.K.; Alzahrani, F.A.; Rezai, H.; Wang, K.; Ahmed, A. Bioenergetic Effects of Hydrogen Sulfde Suppress Soluble Flt 1 and Soluble Endoglin in Cystathionine Gamma Lyase Compromised Endothelial Cells. Sci. Rep. 2020, 10, 15810-15820. [CrossRef]

37. Papapetropoulos, A.; Pyriochou, A.; Altaany, Z.; Yang, G.; Marazioti, A.; Zhou, Z.; Jeschke, M.G.; Branski, L.K.; Herndon, D.N.; Wang, R.; et al. Hydrogen Sulfide Is an Endogenous Stimulator of Angiogenesis. Proc. Natl. Acad. Sci. USA 2009, 106, $21972-21977$. [CrossRef]

38. Hughes, M.N.; Centelles, M.N.; Moore, K.P. Making and Working with Hydrogen Sulfide. Free. Radic. Biol. Med. 2009, 47, 1346-1353. [CrossRef] [PubMed]

39. Ozturk, T.; Ertas, A.E.; Mert, O. Use of Lawesson's Reagent in Organic Syntheses. Chem. Rev. 2007, 107, 5210-5278. [CrossRef] [PubMed]

40. Li, L.; Whiteman, M.; Guan, Y.Y.; Neo, K.L.; Cheng, Y.; Lee, S.W.; Zhao, Y.; Baskar, R.; Tan, C.H.; Moore, P.K. Characterization of a Novel, Water-Soluble Hydrogen SulfiDe-releasing Molecule (GYY4137): New Insights into the Biology of Hydrogen Sulfide. Circulation 2008, 117, 2351-2360. [CrossRef]

41. Rose, P.; Dymock, B.W.; Moore, P.K. GYY4137, a Novel Water-Soluble, $\mathrm{H}_{2}$ S-Releasing Molecule. Methods Enzymol. 2015, 554, 143-167. [CrossRef]

42. Park, C.; Zhao, Y.; Zhu, Z.; Pacheco, A.; Peng, B.; Devarie-Baez, N.O.; Bagdon, P.; Zhang, H.; Xian, M. Synthesis and Evaluation of Phosphorodithioate-Based Hydrogen Sulfide Donors. Mol. Biosyst. 2013, 9, 2430-2434. [CrossRef] [PubMed]

43. Brodnitz, M.H.; Pascale, J.V.; Van Derslice, L. Flavor Components of Garlic Extract. J. Agric. Food Chem. 1971, 19, 273-275. [CrossRef]

44. Rahman, M.S. Allicin and Other Functional Active Components in Garlic: Health Benefits and Bioavailability. Int. J. Food Prop. 2007, 10, 245-268. [CrossRef]

45. Rana, S.V.; Pal, R.; Vaiphei, K.; Sharma, S.K.; Ola, R.P. Garlic in Health and Disease. Nutr. Res. Rev. 2011, 24, 60-71. [CrossRef] [PubMed]

46. Butt, M.S.; Sultan, M.T.; Butt, M.S.; Iqbal, J. Garlic: Nature's Protection against Physiological Threats. Crit. Rev. Food Sci. Nutr. 2009, 49, 538-551. [CrossRef]

47. Citi, V.; Martelli, A.; Testai, L.; Marino, A.; Breschi, M.C.; Calderone, V. Hydrogen Sulfide Releasing Capacity of Natural Isothiocyanates: Is It a Reliable Explanation for the Multiple Biological Effects of Brassicaceae? Planta Medica 2014, 80, 610-613. [CrossRef]

48. Zhou, Z.; Rekowski, M.V.W.; Coletta, C.; Szabo, C.; Bucci, M.; Cirino, G.; Topouzis, S.; Papapetropoulos, A.; Giannis, A. Thioglycine and L-Thiovaline: Biologically Active $\mathrm{H}_{2}$ S-donors. Bioorganic Med. Chem. 2012, 20, 2675-2678. [CrossRef] 
49. Zhao, Y.; Wang, H.; Xian, M. Cysteine-Activated Hydrogen Sulfide $\left(\mathrm{H}_{2} \mathrm{~S}\right)$ Donors. J. Am. Chem. Soc. 2010, 133, 15-17. [CrossRef] [PubMed]

50. Zhao, Y.; Bhushan, S.; Yang, C.; Otsuka, H.; Stein, J.D.; Pacheco, A.; Peng, B.; Devarie-Baez, N.O.; Aguilar, H.C.; Lefer, D.J.; et al. Controllable Hydrogen Sulfide Donors and Their Activity against Myocardial Ischemia-Reperfusion Injury. ACS Chem. Biol. 2013, 8, 1283-1290. [CrossRef]

51. Roger, T.; Raynaud, F.; Bouillaud, F.; Ransy, C.; Simonet, S.; Crespo, C.; Bourguignon, M.-P.; Villeneuve, N.; Vilaine, J.-P.; Artaud, I.; et al. New Biologically Active Hydrogen Sulfide Donors. ChemBioChem 2013, 14, 2268-2271. [CrossRef] [PubMed]

52. Martelli, A.; Testai, L.; Citi, V.; Marino, A.; Pugliesi, I.; Barresi, E.; Nesi, G.; Rapposelli, S.; Taliani, S.; Da Settimo, F.; et al. Arylthioamides as $\mathrm{H}_{2} \mathrm{~S}$ Donors: L-Cysteine-Activated Releasing Properties and Vascular Effects in Vitro and in Vivo. ACS Med. Chem. Lett. 2013, 4, 904-908. [CrossRef]

53. Severino, B.; Corvino, A.; Fiorino, F.; Luciano, P.; Frecentese, F.; Magli, E.; Saccone, I.; Di Vaio, P.; Citi, V.; Calderone, V.; et al. 1,2,4-Thiadiazolidin-3,5-diones as Novel Hydrogen Sulfide Donors. Eur. J. Med. Chem. 2018, 143, 1677-1686. [CrossRef] [PubMed]

54. Barresi, E.; Nesi, G.; Citi, V.; Piragine, E.; Piano, I.; Taliani, S.; Da Settimo, F.; Rapposelli, S.; Testai, L.; Breschi, M.C.; et al. Iminothioethers as Hydrogen Sulfide Donors: From the Gasotransmitter Release to the Vascular Effects. J. Med. Chem. 2017, 60, 7512-7523. [CrossRef]

55. Mitidieri, E.; Tramontano, T.; Gurgone, D.; Citi, V.; Calderone, V.; Brancaleone, V.; Katsouda, A.; Nagahara, N.; Pa-papetropoulos, A.; Cirino, G.; et al. Mercaptopyruvate Acts as Endogenous Vasodi-Lator Independently of 3-Mercaptopyruvate Sulfurtransferase Activity. Nitric Oxide 2018, 75, 53-59. [CrossRef] [PubMed]

56. Ercolano, G.; De Cicco, P.; Frecentese, F.; Saccone, I.; Corvino, A.; Giordano, F.; Magli, E.; Fiorino, F.; Severino, B.; Calderone, V.; et al. Anti-metastatic Properties of Naproxen-HBTA in a Murine Model of Cutaneous Melanoma. Front. Pharmacol. 2019, 10, 66. [CrossRef]

57. Martelli, A.; Testai, L.; Citi, V.; Marino, A.; Bellagambi, F.G.; Ghimenti, S.; Breschi, M.C.; Calderone, V. Pharmacological Characterization of the Vascular Effects of Aryl Isothiocyanates: Is Hydrogen Sulfide the Real Player? Vasc. Pharmacol. 2014, 60, 32-41. [CrossRef] [PubMed]

58. Citi, V.; Corvino, A.; Fiorino, F.; Frecentese, F.; Magli, E.; Perissutti, E.; Santagada, V.; Brogi, S.; Flori, L.; Gorica, E.; et al. Structure-Activity Relationships Study of Isothiocyanates for $\mathrm{H}_{2} \mathrm{~S}$ Releasing Properties: 3-Pyridyl-Isothiocyanate as a New Promising Cardioprotective Agent. J. Adv. Res. 2021, 27, 41-53. [CrossRef]

59. Zhao, Y.; Steiger, A.K.; Pluth, M.D. Cyclic Sulfenyl Thiocarbamates Release Carbonyl Sulfide and Hydrogen Sulfide Independently in Thiol-Promoted Pathways. J. Am. Chem. Soc. 2019, 141, 13610-13618. [CrossRef] [PubMed]

60. Esechie, A.; Kiss, L.; Olah, G.; Horváth, E.M.; Hawkins, H.; Szabo, C.; Traber, D.L. Protective Effect of Hydrogen Sulfide in a Murine Model of Acute Lung Injury Induced by Combined Burn and Smoke Inhalation. Clin. Sci. 2008, 115, 91-97. [CrossRef] [PubMed]

61. Kloesch, B.; Liszt, M.; Steiner, G.; Bro“1l, J. Inhibitors of p38 and ERK1/2 Mapkinase and Hydrogen Sulphide Block Constitutive and IL-1ß-Induced IL-6 and IL-8 Expression in the Human Chondrocyte Cell Line C-28/I2. Rheumatol. Int. 2012, $32,729$. [CrossRef] [PubMed]

62. Li, T.; Zhao, B.; Wang, C.; Wang, H.; Liu, Z.; Li, W.; Jin, H.; Tang, C.; Du, J. Regulatory Effects of Hydrogen Sulfide on IL-6, IL-8 and IL-10 Levels in the Plasma and Pulmonary Tissue of Rats with Acute Lung Injury. Exp. Biol. Med. 2008, 233, $1081-1087$. [CrossRef] [PubMed]

63. Ali, F.F.; Abdel-Hamid, H.A.; Toni, N.D. $\mathrm{H}_{2} \mathrm{~S}$ Attenuates Acute Lung Inflammation Induced by Administration of LipopolysacCharide in Adult Male Rats. Gen. Physiol. Biophys. 2018, 37, 421-431. [CrossRef]

64. Whiteman, M.; Cheung, N.S.; Zhu, Y.-Z.; Chu, S.H.; Siau, J.L.; Wong, B.S.; Armstrong, J.S.; Moore, P.K. Hydrogen Sulphide: A Novel Inhibitor of Hypochlorous Acid-Mediated Oxidative Damage in the Brain? Biochem. Biophys. Res. Commun. 2005, 326, 794-798. [CrossRef]

65. Cao, L.; Cao, X.; Zhou, Y.; Nagpure, B.V.; Wu, Z.-Y.; Hu, L.F.; Yang, Y.; Sethi, G.; Moore, P.K.; Bian, J.-S. Hydrogen Sulfide Inhibits ATP-Induced Neuroinflammation and a $\beta 1-42$ Synthesis by Suppressing the Activation of STAT3 and Cathepsin S. Brain Behav. Immun. 2018, 73, 603-614. [CrossRef]

66. Du, C.; Lin, X.; Xu, W.; Zheng, F.; Cai, J.; Yang, J.; Cui, Q.; Tang, C.; Cai, J.; Xu, G.; et al. Sulfhydrated Sirtuin-1 Increasing Its Deacetylation Activity Is an Essential Epigenetics Mechanism of Anti-Atherogenesis by Hydrogen Sulfide. Antioxid. Redox Signal. 2019, 30, 184-197. [CrossRef]

67. Wallace, J.L.; Vong, L.; McKnight, W.; Dicay, M.; Martin, G.R. Endogenous and Exogenous Hydrogen Sulfide Promotes Resolu-Tion of Colitis in Rats. Gastroenterology 2009, 137, 569-578. [CrossRef] [PubMed]

68. Wallace, J.L.; Dicay, M.; McKnight, W.; Martin, G.R. Hydrogen Sulfide Enhances Ulcer Healing in Rats. FASEB J. 2007, 21, 4070-4076. [CrossRef]

69. Elrod, J.W.; Calvert, J.W.; Morrison, J.; Doeller, J.E.; Kraus, D.W.; Tao, L.; Jiao, X.; Scalia, R.; Kiss, L.; Szabo, C.; et al. Hydrogen Sulfide Attenuates Myocardial Ischemia-Reperfusion Injury by Preservation of Mitochondrial Function. Proc. Natl. Acad. Sci. USA 2007, 104, 15560-15565. [CrossRef]

70. Calvert, J.W.; Jha, S.; Gundewar, S.; Elrod, J.W.; Ramachandran, A.; Pattillo, C.B.; Kevil, C.G.; Lefer, D.J. Hydrogen Sulfide Mediates Cardioprotection Through Nrf2 Signaling. Circ. Res. 2009, 105, 365-374. [CrossRef] 
71. Pan, T.-T.; Chen, Y.Q.; Bian, J.-S. All in the Timing: A Comparison between the Cardioprotection Induced by $\mathrm{H}_{2} \mathrm{~S}$ Preconditioning and Post-infarction Treatment. Eur. J. Pharmacol. 2009, 616, 160-165. [CrossRef]

72. Andreadou, I.; Iliodromitis, E.K.; Rassaf, T.; Schulz, R.; Papapetropoulos, A.; Ferdinandy, P. The Role of Gasotransmitters NO, $\mathrm{H}_{2} \mathrm{~S}$ and $\mathrm{CO}$ in Myocardial Ischaemia/Reperfusion Injury and Cardioprotection by Preconditioning, Postconditioning and Remote Conditioning. Br. J. Pharmacol. 2015, 172, 1587-1606. [CrossRef]

73. Andreadou, I.; Iliodromitis, E.K.; Szabo, C.; Papapetropoulos, A. Hydrogen Sulfide and PKG in Ischemia-Reperfusion Injury: Sources, Signaling, Accelerators and Brakes. Basic Res. Cardiol. 2015, 110, 1-6. [CrossRef]

74. Mard, S.A.; Neisi, N.; Solgi, G.; Hassanpour, M.; Darbor, M.; Maleki, M. Gastroprotective Effect of NaHS against Mucosal Le-Sions Induced by Ischemia-Reperfusion Injury in Rat. Dig. Dis. Sci. 2012, 57, 1496-1503. [CrossRef]

75. Li, N.; Wang, M.-J.; Jin, S.; Bai, Y.-D.; Hou, C.-L.; Ma, F.-F.; Li, X.-H.; Zhu, Y.-C. The $\mathrm{H}_{2} \mathrm{~S}$ Donor NaHS Changes the Expression Pattern of $\mathrm{H}_{2} \mathrm{~S}$-Producing Enzymes after Myocardial Infarction. Oxidative Med. Cell. Longev. 2016, 2016, 1-11. [CrossRef]

76. Gao, C.; Xu, D.Q.; Gao, C.J.; Ding, Q.; Yao, L.N.; Li, Z.C.; Chai, W. An Exogenous Hydrogen Sulphide Donor, NaHS, Inhibits the Nuclear Factor кB Inhibitor Kinase/Nuclear Factor кB Inhibitor/Nuclear Factor- $\kappa$ B Signaling Pathway and Exerts Cardioprotective Effects in a Rat Hemorrhagic Shock Model. Biol. Pharm. Bull. 2012, 35, 1029-1034. [CrossRef]

77. Chen, K.Y.; Morris, J.C. Kinetics of Oxidation of Aqueous Sulfide by Oxygen. Environ. Sci. Technol. 1972, 6, 529-537. [CrossRef]

78. Benavides, G.A.; Squadrito, G.L.; Mills, R.W.; Patel, H.D.; Isbell, T.S.; Patel, R.P.; Darley-Usmar, V.M.; Doeller, J.E.; Kraus, D.W. Hydrogen Sulfide Mediates the Vasoactivity of Garlic. Proc. Natl. Acad. Sci. USA 2007, 104, 17977-17982. [CrossRef] [PubMed]

79. Qidwai, W.; Ashfaq, T. Role of Garlic Usage in Cardiovascular Disease Prevention: An Evidence-Based Approach. Evidence-Based Complement. Altern. Med. 2013, 2013, 1-9. [CrossRef] [PubMed]

80. Polhemus, D.J.; Calvert, J.W.; Butler, J.; Lefer, D.J. The Cardioprotective Actions of Hydrogen Sulfide in Acute Myocardial in-Farction and Heart Failure. Scientifica 2014, 768607, 1-8. [CrossRef] [PubMed]

81. Bahadoran, Z.; Mirmiran, P.; Momenan, A.A.; Azizi, F. Allium Vegetable Intakes and the Incidence of Cardiovascular Disease, Hypertension, Chronic Kidney Disease, and Type 2 Diabetes in Adults. J. Hypertens. 2017, 35, 1909-1916. [CrossRef] [PubMed]

82. Chan, J.Y.-Y.; Yuen, A.C.-Y.; Chan, R.Y.-K.; Chan, S.-W. A Review of the Cardiovascular Benefits and Antioxidant Properties of Allicin. Phytother. Res. 2012, 27, 637-646. [CrossRef] [PubMed]

83. Herrera-Mundo, M.N.; Silva-Adaya, D.; Maldonado, P.D.; Galván-Arzate, S.; Andrés-Martínez, L.; La Cruz, V.P.-D.; PedrazaChaverri, J.; Santamaría, A. S-Allylcysteine Prevents the Rat from 3-Nitropropionic Acid-Induced Hyperactivity, Early Markers of Oxidative Stress and Mitochondrial Dysfunction. Neurosci. Res. 2006, 56, 39-44. [CrossRef]

84. Numagami, Y.; Ohnishi, S.T. S-Allylcysteine Inhibits Free Radical Production, Lipid Peroxidation and Neuronal Damage in Rat Brain Ischemia. J. Nutr. 2001, 131, 1100S-1105S. [CrossRef]

85. Welch, C.; Wuarin, L.; Sidell, N. Anti-Proliferative Effect of the Garlic Compound S-Allylcysteine on Human Neuroblastoma Cell in Vitro. Cancer Lett. 1992, 63, 211-219. [CrossRef]

86. Chu, Q.; Lee, D.T.; Tsao, S.W.; Wang, X.; Wong, Y.C. S-Allylcysteine, a Water-Soluble Garlic Derivative, Suppresses the Growth of a Human Androgen-Independent Prostate Cancer Xenograft, CWR22R, Under in Vivo Conditions. BJU Int. 2007, 99, $925-932$. [CrossRef] [PubMed]

87. Hsu, C.C.; Lin, C.C.; Liao, T.S.; Yin, M.C. Protective Effect of S-Allylcysteine and S-Propyl Cysteine on Acetaminophen-Induced Hepatotoxicity in Mice. Food Chem. Toxicol. 2006, 44, 393-397. [CrossRef] [PubMed]

88. Nakagawa, S.; Kasuga, S.; Matsura, H. Prevention of Liver Damage by Aged Garlic Extract and Its Components in Mice. Phytother. Res. 1989, 3, 50-53. [CrossRef]

89. Padmanabhan, M.; Prince, P.S.M. Preventive Effect of S-Allylcysteine on Lipid Peroxides and Antioxidants in Normal and Isoproterenol-Induced Cardiotoxicity in Rats: A Histopathological Study. Toxicology 2006, 224, 128-137. [CrossRef]

90. Chuah, S.C.; Moore, P.K.; Zhu, Y.Z. S-Allylcysteine Mediates Cardioprotection in an Acute Myocardial Infarction Rat Model via a Hydrogen SulfiDe-mediated Pathway. Am. J. Physiol. Circ. Physiol. 2007, 293, H2693-H2701. [CrossRef] [PubMed]

91. Wang, Q.; Liu, H.-R.; Mu, Q.; Rose, P.; Zhu, Y.Z. S-propargyl-cysteine Protects Both Adult Rat Hearts and Neonatal Cardiomyocytes From Ischemia/Hypoxia Injury: The Contribution of the Hydrogen Sulfide-Mediated Pathway. J. Cardiovasc. Pharmacol. 2009, 54, 139-146. [CrossRef]

92. Wang, Q.; Wang, X.-L.; Liu, H.-R.; Rose, P.; Zhu, Y.-Z. Protective Effects of Cysteine Analogues on Acute Myocardial Ischemia: Novel Modulators of Endogenous $\mathrm{H}_{2} \mathrm{~S}$ Production. Antioxidants Redox Signal. 2010, 12, 1155-1165. [CrossRef]

93. Ried, K.; Frank, O.; Stocks, N.P. Aged Garlic Extract Reduces Blood Pressure in Hypertensives: A Dose-Response Trial. Eur. J. Clin. Nutr. 2012, 67, 64-70. [CrossRef]

94. Jacob, C.; Anwar, A.; Burkholz, T. Perspective on Recent Developments on Sulfur-Containing Agents and Hydrogen Sulfide Signaling. Planta Medica 2008, 74, 1580-1592. [CrossRef]

95. Kashfi, K.; Olson, K.R. Biology and Therapeutic Potential of Hydrogen Sulfide and Hydrogen SulfiDe-releasing Chimeras. Biochem. Pharmacol. 2013, 85, 689-703. [CrossRef] [PubMed]

96. Li, L.; Hsu, A.; Moore, P.K. Actions and Interactions of Nitric Oxide, Carbon Monoxide and Hydrogen Sulphide in the Cardiovascular System and in Inflammation-a Tale of Three Gases! Pharmacol. Ther. 2009, 123, 386. [CrossRef]

97. Nicholson, C.K.; Calvert, J.W. Hydrogen Sulfide and Ischemia-Reperfusion Injury. Pharmacol. Res. 2010, 62, 289. [CrossRef]

98. Olson, K.R. The Therapeutic Potential of Hydrogen Sulfide: Separating Hype from Hope. Am. J. Physiol. Integr. Comp. Physiol. 2011, 301, R297-R312. [CrossRef] 
99. Predmore, B.L.; Lefer, D.J.; Gojon, G. Hydrogen Sulfide in Biochemistry and Medicine. Antioxid. Redox Signal. 2012, 17, 119-140. [CrossRef] [PubMed]

100. Dinkova-Kostova, A.T.; Kostov, R.V. Glucosinolates and Isothiocyanates in Health and Disease. Trends Mol. Med. 2012, 18, 337-347. [CrossRef] [PubMed]

101. Lin, Y.; Yang, X.; Lu, Y.; Liang, D.; Huang, D. Isothiocyanates as $\mathrm{H}_{2} \mathrm{~S}$ Donors Triggered by Cysteine: Reaction Mechanism and Structure and Activity Relationship. Org. Lett. 2019, 21, 5977-5980. [CrossRef]

102. Zhao, Y.; Biggs, T.D.; Xian, M. Hydrogen Sulfide $\left(\mathrm{H}_{2} \mathrm{~S}\right)$ Releasing Agents: Chemistry and Biological Applications. Chem. Commun. 2014, 50, 11788-11805. [CrossRef] [PubMed]

103. Lecher, H.Z.; Greenwood, R.A.; Whitehouse, K.C.; Chao, T.H. The Phosphonation of Aromatic Compounds with Phosphorus Pentasulfide. J. Am. Chem. Soc. 1956, 78, 5018-5022. [CrossRef]

104. Thomsen, I.; Clausen, K.; Scheibye, S.; Lawesson, S.-O. Thiation with 2,4-Bis(4-Methoxyphenyl)-1,3,2,4- Dithiadiphosphetane 2,4-Disulfide:N-Methylthiopyrrolidone. Organic Syntheses 2003, 62, 158. [CrossRef]

105. Karwi, Q.G.; Whiteman, M.; Wood, M.E.; Torregrossa, R.; Baxter, G.F. Pharmacological Postconditioning against Myocardial Infarction with a Slow-Releasing Hydrogen Sulfide Donor, GYY4137. Pharmacol. Res. 2016, 111, 442-451. [CrossRef] [PubMed]

106. Qiu, Y.; Wu, Y.; Meng, M.; Luo, M.; Zhao, H.; Sun, H.; Gao, S. GYY4137 Protects against Myocardial Ischemia/Reperfusion Injury via Activation of the PHLPP-1/Akt/Nrf2 Signaling Pathway in Diabetic Mice. J. Surg. Res. 2018, 225, 29-39. [CrossRef]

107. Alexander, B.E.; Coles, S.J.; Fox, B.C.; Khan, T.F.; Maliszewski, J.; Perry, A.; Pitak, M.B.; Whiteman, M.; Wood, M.E. Investigating the Generation of Hydrogen Sulfide from the Phosphonamidodithioate Slow-Release Donor GYY4137. MedChemComm 2015, 6, 1649-1655. [CrossRef]

108. Moore, P.K.; Whiteman, M. Chemistry, Biochemistry and Pharmacology of Hydrogen Sulfide; Springer: Amsterdam, The Netherlands, 2015; pp. 344-354.

109. Landis, P.S. The Chemistry of 1,2-Dithiole-3-thiones. Chem. Rev. 1965, 65, 237-245. [CrossRef]

110. Curphey, T.J.; Libby, A.A. Dianions of 3-Oxo dithioic Acids: Preparation and Conversion to 3H-1,2-Dithiole-3-thiones. Tetrahedron Lett. 2000, 41, 6977. [CrossRef]

111. Pedersen, B.S.; Lawesson, S.O. Syntheses of 3H-1,2-Dithiole-3-Thiones and 4H-1,3,2-Oxazaphosphorine Derivatives from the Dimer of P-Methoxyphenyl-Thionophosphine Sulfide and Der. Tetrahedron 1979, 35, 2433-2437. [CrossRef]

112. Hamada, T.; Nakane, T.; Kimura, T.; Arisawa, K.; Yoneda, K.; Yamamoto, T.; Osaki, T. Treatment of Xerostomia with the Bile Secretion-Stimulating Drug Anethole Trithione: A Clinical Trial. Am. J. Med. Sci. 1999, 318, 146-151. [CrossRef]

113. Perrino, E.; Cappelletti, G.; Tazzari, V.; Giavini, E.; Del Soldato, P.; Sparatore, A. New Sulfurated Derivatives of Valproic Acid with Enhanced Histone Deacetylase Inhibitory Activity. Bioorganic Med. Chem. Lett. 2008, 18, 1893-1897. [CrossRef]

114. Tazzari, V.; Cappelletti, G.; Casagrande, M.; Perrino, E.; Renzi, L.; Del Soldato, P.; Sparatore, A. New Aryldithiolethione Derivatives as Potent Histone Deacetylase Inhibitors. Bioorganic Med. Chem. 2010, 18, 4187-4194. [CrossRef]

115. Sen, C.K.; Traber, K.E.; Packer, L. Inhibition of NF-jB Activation in Human T-cell Lines by Anetholdithiolthione. Biochem. Biophys. Res. Commun. 1996, 218, 148-153. [CrossRef] [PubMed]

116. Zanatta, S.D.; Jarrott, B.; Williams, S.J. Synthesis and Preliminary Pharmacological Evaluation of Aryl Dithiolethiones with Cyclooxygenase-2-Selective Inhibitory Activity and Hydrogen Sulfide-Releasing Properties. Aust. J. Chem. 2010, 63, 946-957. [CrossRef]

117. Qandil, A.M. Prodrugs of Nonsteroidal Anti-Inflammatory Drugs (NSAIDs), More Than Meets the Eye: A Critical Review. Int. J. Mol. Sci. 2012, 13, 17244-17274. [CrossRef]

118. Caliendo, G.; Cirino, G.; Santagada, V.; Wallace, J.L. Synthesis and Biological Effects of Hydrogen Sulfide ( $\left.\mathrm{H}_{2} \mathrm{~S}\right)$ : Development of $\mathrm{H}_{2}$ S-Releasing Drugs as Pharmaceuticals. J. Med. Chem. 2010, 53, 6275-6286. [CrossRef] [PubMed]

119. Li, L.; Rossoni, G.; Sparatore, A.; Lee, L.C.; Del Soldato, P.; Moore, P.K. Anti-inflammatory and gastrointestinal effects of a novel diclofenac derivative. Free. Radic. Biol. Med. 2007, 42, 706-719. [CrossRef] [PubMed]

120. Wallace, J.L.; Caliendo, G.; Santagada, V.; Cirino, G.; Fiorucci, S. Gastrointestinal Safety and Anti-Inflammatory Effects of a Hydrogen Sulfide-Releasing Diclofenac Derivative in the Rat. Gastroenterology 2007, 132, 261-271. [CrossRef]

121. Fiorucci, S.; Orlandi, S.; Mencarelli, A.; Caliendo, G.; Santagada, V.; Distrutti, E.; Santucci, L.; Cirino, G.; Wallace, J.L. Enhanced Activity of a Hydrogen SulphiDe-releasing Derivative of Mesalamine (ATB-429) in a Mouse Model of Colitis. Br. J. Pharmacol. 2007, 150, 996-1002. [CrossRef] [PubMed]

122. Chattopadhyay, M.; Kodela, R.; Nath, N.; Dastagirzada, Y.M.; Velázquez-Martínez, C.A.; Boring, D.; Kashfi, K. Hydrogen SulfiDereleasing NSAIDS Inhibit the Growth of Human Cancer Cells: A General Property and Evidence of a Tissue Type-Independent Effect. Biochem. Pharmacol. 2012, 83, 715-722. [CrossRef]

123. Shukla, N.; Rossoni, G.; Hotston, M.; Sparatore, A.; Del Soldato, P.; Tazzari, V.; Persad, R.; Angelini, G.D.; Jeremy, J.Y. Effect of Hydrogen SulfiDe-donating Sildenafil (acs6) on Erectile Function and Oxidative Stress in Rabbit Isolated Corpus Cavernosum and in Hypertensive Rats. BJU Int. 2009, 103, 1522-1529. [CrossRef]

124. Perrino, E.; Uliva, C.; Lanzi, C.; Del Soldato, P.; Masini, E.; Sparatore, A. New Prostaglandin Derivative for Glaucoma Treatment. Bioorg. Med. Chem. Lett. 2009, 19, 1639-1642. [CrossRef]

125. Lee, M.; Tazzari, V.; Giustarini, D.; Rossi, R.; Sparatore, A.; Del Soldato, P.; McGeer, E.; McGeer, P.L. Effects of Hydrogen Sulfide-releasing 1-DOPA Derivatives on Glial Activation. J. Biol. Chem. 2010, 285, 17318-17328. [CrossRef] 
126. Rossoni, G.; Manfredi, B.; Tazzari, V.; Sparatore, A.; Trivulzio, S.; Del Soldato, P.; Berti, F. Activity of a New Hydrogen SulfiDereleasing Aspirin (ACS14) on Pathological Cardiovascular Alterations Induced by Glutathione Depletion in Rats. Eur. J. Pharmacol. 2010, 648, 139-145. [CrossRef] [PubMed]

127. Kodela, R.; Chattopadhyay, M.; Kashfi, K. NOSH-Aspirin: A Novel Nitric Oxide-Hydrogen Sulfide-Releasing Hybrid: A New Class of Anti-inflammatory Pharmaceuticals. ACS Med. Chem. Lett. 2012, 3, 257-262. [CrossRef] [PubMed]

128. Rossoni, G.; Berti, M.; Colonna, V.D.; Bernareggi, M.; Del Soldato, P.; Berti, F. Myocardial Protection by the Nitroderivative of Aspirin, NCX 4016: In Vitro and in Vivo Experiments in the Rabbit. Ital. Hear. J. Off. J. Ital. Fed. Cardiol. 2000, 1, $146-155$.

129. Szczesny, B.; Módis, K.; Yanagi, K.; Coletta, C.; Le Trionnaire, S.; Perry, A.; Wood, M.E.; Whiteman, M.; Szabo, C. AP39, A Novel Mitochondria-Targeted Hydrogen Sulfide Donor, Stimulates Cellular Bioenergetics, Exerts Cytoprotective Effects and Protects against the Loss of Mitochondrial DNA Integrity in Oxidatively Stressed Endothelial Cells in Vitro. Nitric Oxide 2014, 41, 120-130. [CrossRef] [PubMed]

130. Ikeda, K.; Marutani, E.; Hirai, S.; Wood, M.E.; Whiteman, M.; Ichinose, F. Mitochondria-Targeted Hydrogen Sulfide Donor AP39 Improves Neurological Outcomes after Cardiac Arrest in Mice. Nitric Oxide 2015, 49, 90-96. [CrossRef] [PubMed]

131. Ahmad, A.; Olah, G.; Szczesny, B.; Wood, M.E.; Whiteman, M.; Szabo, C. AP39, A Mitochondrially Targeted Hydrogen Sulfide Donor, Exerts Protective Effects in Renal Epithelial Cells Subjected to Oxidative Stress in Vitro and in Acute Renal Injury in Vivo. Shock 2016, 45, 88-97. [CrossRef] [PubMed]

132. Chatzianastasiou, A.; Bibli, S.-I.; Andreadou, I.; Efentakis, P.; Kaludercic, N.; Wood, M.E.; Whiteman, M.; Di Lisa, F.; Daiber, A.; Manolopoulos, V.G.; et al. Cardioprotection by $\mathrm{H}_{2} \mathrm{~S}$ Donors: Nitric Oxide-Dependent and -Independent Mechanisms. J. Pharmacol. Exp. Ther. 2016, 358, 431-440. [CrossRef] [PubMed]

133. Karwi, Q.G.; Bornbaum, J.; Boengler, K.; Torregrossa, R.; Whiteman, M.; Wood, M.E.; Schulz, R.; Baxter, G.F. AP39, A MitochondriaTargeting Hydrogen Sulfide $\left(\mathrm{H}_{2} \mathrm{~S}\right)$ Donor, Protects against Myocardial Reperfusion Injury Independently of Salvage Kinase Signalling. Br. J. Pharmacol. 2017, 174, 287-301. [CrossRef] [PubMed]

134. Kang, J.; Li, Z.; Organ, C.L.; Park, C.M.; Yang, C.T.; Pacheco, A.; Wang, D.; Lefer, D.J.; Xian, M. pH-Controlled Hydrogen Sulfide Release for Myocardial Ischemia-Reperfusion Injury. J. Am. Chem. Soc. 2016, 138, 6336-6339. [CrossRef]

135. Wang, H.; Skeldon, P.; Thompson, G.; Wood, G. Synthesis and Characterization of Molybdenum Disulphide Formed from Ammonium Tetrathiomolybdate. J. Mater. Sci. 1997, 32, 497-502. [CrossRef]

136. Xu, S.; Yang, C.-T.; Meng, F.-H.; Pacheco, A.; Chen, L.; Xian, M. Ammonium Tetrathiomolybdate as a Water-Soluble and Slow-Release Hydrogen Sulfide Donor. Bioorganic Med. Chem. Lett. 2016, 26, 1585-1588. [CrossRef]

137. Dyson, A.; Dal-Pizzol, F.; Sabbatini, G.; Lach, A.B.; Galfo, F.; Cardoso, J.D.S.; Mendonça, B.P.; Hargreaves, I.; Pinto, B.B.; Bromage, D.I.; et al. Ammonium Tetrathiomolybdate Following Ischemia/Reperfusion Injury: Chemistry, Pharmacology, and Impact of a New Class of Sulfide Donor in Preclinical Injury Models. PLoS Med. 2017, 14, e1002310. [CrossRef]

138. Zhang, H.; Zhang, A.; Guo, C.; Shi, C.; Zhang, Y.; Liu, Q.; Sparatore, A.; Wang, C. S-diclofenac Protects against DoxorubicinInduced Cardiomyopathy in Mice via Ameliorating Cardiac Gap Junction Remodeling. PLoS ONE 2011, 6, e26441. [CrossRef] [PubMed]

139. Wu, J.; Guo, W.; Lin, S.-Z.; Wang, Z.-J.; Kan, J.-T.; Chen, S.-Y.; Zhu, Y.-Z. Gp130-Mediated STAT3 Activation by S-Propargylcysteine, an Endogenous Hydrogen Sulfide Initiator, Prevents Doxorubicin-Induced Cardiotoxicity. Cell Death Dis. 2016, 7, e2339. [CrossRef]

140. Su, Y.-W.; Liang, C.; Jin, H.-F.; Tang, X.-Y.; Han, W.; Chai, L.-J.; Zhang, C.-Y.; Geng, B.; Tang, C.-S.; Du, J.-B. Hydrogen Sulfide Regulates Cardiac Function and Structure in Adriamycin-Induced Cardiomyopathy. Circ. J. 2009, 73, 741-749. [CrossRef] [PubMed]

141. Chan, N.; Willis, A.; Kornhauser, N.; Ward, M.M.; Lee, S.B.; Nackos, E.; Seo, B.R.; Chuang, E.; Cigler, T.; Moore, A.; et al. Influencing the Tumor Microenvironment: A Phase II Study of Copper Depletion Using Tetrathiomolybdate in Patients with Breast Cancer at High Risk for Recurrence and in Preclinical Models of Lung Metastases. Clin. Cancer Res. 2017, 23, 666-676. [CrossRef] [PubMed]

142. Yang, C.-T.; Zhao, Y.; Xian, M.; Li, J.-H.; Dong, Q.; Bai, H.-B.; Xu, J.-D.; Zhang, M.-F. A Novel Controllable Hydrogen Sulfide-Releasing Molecule Protects Human Skin Keratinocytes Against Methylglyoxal-Induced Injury and Dysfunction. Cell. Physiol. Biochem. 2014, 34, 1304-1317. [CrossRef]

143. Zhao, Y.; Yang, C.; Organ, C.; Li, Z.; Bhushan, S.; Otsuka, H.; Pacheco, A.; Kang, J.; Aguilar, H.C.; Lefer, D.J.; et al. Design, Synthesis, and Cardioprotective Effects of N-Mercapto-Based Hydrogen Sulfide Donors. J. Med. Chem. 2015, 58, 7501-7511. [CrossRef] [PubMed]

144. Stipanuk, M.H.; Beck, P.W. Characterization of the Enzymic Capacity for Cysteine Desulphhydration in Liver and Kidney of the Rat. Biochem. J. 1982, 206, 267-277. [CrossRef] [PubMed]

145. Frank, R.L.; Blegen, J.R. Benzoyl Disulfide. Organic Syntheses 2003, 28, 16. [CrossRef]

146. Heimer, N.E.; Field, L.; Neal, R.A. Biologically Oriented Organic Sulfur Chemistry. 21. Hydrodisulfide of a Penicillamine Derivative and Related Compounds. J. Org. Chem. 1981, 46, 1374-1377. [CrossRef]

147. Wallace, J.L.; Caliendo, G.; Santagada, V.; Cirino, G. Markedly Reduced Toxicity of a Hydrogen SulphiDe-releasing Derivative of Naproxen (ATB-346). Br. J. Pharmacol. 2010, 159, 1236-1246. [CrossRef] 
148. De Cicco, P.; Panza, E.; Ercolano, G.; Armogida, C.; Sessa, G.; Pirozzi, G.; Cirino, G.; Wallace, J.L.; Ianaro, A. ATB-346, A Novel Hydrogen SulfiDe-releasing Anti-inflammatory Drug, Induces Apoptosis of Human Melanoma Cells and Inhibits Melanoma Development in Vivo. Pharmacol. Res. 2016, 114, 67-73. [CrossRef]

149. Elsheikh, W.; Blackler, R.W.; Flannigan, K.L.; Wallace, J.L. Enhanced Chemopreventive Effects of a Hydrogen SulfiDe-releasing Anti-inflammatory Drug (ATB-346) in Experimental Colorectal Cancer. Nitric Oxide 2014, 41, 131-137. [CrossRef]

150. Wallace, J.L.; Vaughan, D.; Dicay, M.; Macnaughton, W.K.; De Nucci, G. Hydrogen Sulfide-Releasing Therapeutics: Translation to the Clinic. Antioxidants Redox Signal. 2018, 28, 1533-1540. [CrossRef]

151. Testai, L.; Marino, A.; Piano, I.; Brancaleone, V.; Tomita, K.; Di Cesare Mannelli, L.; Martelli, A.; Citi, V.; Breschi, M.C.; Levi, R.; et al. The Novel $\mathrm{H}_{2} \mathrm{~S}$-donor 4-Carboxyphenyl Isothiocyanate Promotes Cardioprotective Effects against Ischemia/Reperfusion Injury through Activation of mitoK ATP Channels and Reduction of Oxidative Stress. Pharmacol. Res. 2016, 113, 290-299. [CrossRef]

152. Nasim, S.; Crooks, P.A. N-Chlorosuccinimide Is a Convenient Oxidant for the Synthesis of 2,4-disubstituted 1,2,4-thiadiazolidine3,5-diones. Tetrahedron Lett. 2009, 50, 257-259. [CrossRef]

153. Kondo, K.; Bhushan, S.; King, A.L.; Prabhu, S.D.; Hamid, T.; Koenig, S.; Murohara, T.; Predmore, B.L.; Gojon, G., Sr.; Gojon, G., Jr.; et al. $\mathrm{H}_{2} \mathrm{~S}$ Protects against Pressure Overload-Induced Heart Failure via Upregulation of Endothelial Nitric Oxide Synthase. Circulation 2013, 127, 1116-1127. [CrossRef]

154. Gojon-Romanillos, G.; Gojon-Zorrilla, G. Preparation and Compositions of Highly Bioavailable Zerovalent Sulfur and Uses Thereof. U.S. Patent 8771755-B2, 8 July 2014.

155. Rohwerder, T.; Sand, W. The Sulfane Sulfur of Persulfides Is the Actual Substrate of the Sulfur-Oxidizing Enzymes from Acidithiobacillus and Acidiphilium spp. Microbiology 2003, 149, 1699-1710. [CrossRef]

156. Suzuki, I. Oxidation of Elemental Sulfur by an Enzyme System of Thiobacillus Thiooxidans. Biochim. Biophys. Acta (BBA) Gen. Subj. 1965, 104, 359-371. [CrossRef]

157. Suzuki, I.; Werkman, C.H. Glutathione and Sulfur Oxidation by Thiobacillus Thiooxidans. Proc. Natl. Acad. Sci. USA 1959, 45, 239-244. [CrossRef] [PubMed]

158. Barr, L.A.; Shimizu, Y.; Lambert, J.P.; Nicholson, C.K.; Calvert, J.W. Hydrogen Sulfide Attenuates High Fat Diet-Induced Cardiac Dysfunction via the Suppression of Endoplasmic Reticulum Stress. Nitric Oxide 2015, 46, 145-156. [CrossRef]

159. Donnarumma, E.; Rushing, A.M.; Boisvert, S.F.; Scarborough, A.L.; Polhemus, D.J.; Trivedi, R.K.; Lefer, D.J.; Goodchild, T.T. The Novel $\mathrm{H}_{2} \mathrm{~S}$ Pro-drug, SG1002, Preserves Coronary Artery Vascular Reactivity in the Setting of Critical Limb Ischemia in Swine. Circulation 2016, 134, A19028.

160. ClinicalTrials.gov. Assessing the Safety and Ability of SG1002 to Overcome Deficits in Hydrogen Sulfide in Heart Failure Patients. Available online: https:/ / clinicaltrials.gov/ct2/show / NCT01989208 (accessed on 18 January 2021).

161. Polhemus, D.J.; Li, Z.; Pattillo, C.B.; Gojon, G.; Giordano, T.; Krum, H. A Novel Hydrogen Sulfide Prodrug, SG 1002, Promotes Hydrogen Sulfide and Nitric Oxide Bioavailability in Heart Failure Patients. Cardiovasc. Ther. 2015, 33, 216-226. [CrossRef]

162. Borchardt, R.T.; Cohen, L.A. Stereopopulation Control. III. Facilitation of Intramolecular Conjugate Addition of the Carboxyl Group. J. Am. Chem. Soc. 1972, 94, 9175-9182. [CrossRef] [PubMed]

163. Zheng, Y.; Yueqin, Z.; Ji, K.; Pan, Z.; Chittavong, V.; Wang, B. Esterase-Sensitive Prodrugs with Tunable Release Rates and Direct Generation of Hydrogen Sulfide. Angew. Chem. Int. Ed. 2016, 55, 4514-4518. [CrossRef]

164. Rao, Y.; Li, X.; Nagorny, P.; Hayashida, J.; Danishefsky, S.J. A Simple Method for the Conversion of Carboxylic Acids into Thioacids with Lawesson's Reagent. Tetrahedron Lett. 2009, 50, 6684-6686. [CrossRef]

165. Li, Z.; Organ, C.L.; Zheng, Y.; Wang, B.; Lefer, D.J. Abstract 17903: Novel Esterase Activated Hydrogen Sulfide Donors Attenuate Myocardial Ischemia/ Reperfusion Injury. Circulation 2016, 134, A17903.

166. Chengelis, C.P.; Neal, R.A. Studies of Carbonyl Sulfide Toxicity: Metabolism by Carbonic Anhydrase. Toxicol. Appl. Pharmacol. 1980, 55, 198-202. [CrossRef]

167. Chengelis, C.P.; Neal, R.A. Hepatic Carbonyl Sulfide Metabolism. Biochem. Biophys. Res. Commun. 1979, 90, 993-999. [CrossRef]

168. Steiger, A.K.; Marcatti, M.; Szabo, C.; Szczesny, B.; Pluth, M.D. Inhibition of Mitochondrial Bioenergetics by Esterase-Triggered COS $/ \mathrm{H}_{2}$ S Donors. ACS Chem. Biol. 2017, 12, 2117-2123. [CrossRef] [PubMed]

169. Steiger, A.K.; Pardue, S.; Kevil, C.G.; Pluth, M.D. Self-Immolative Thiocarbamates Provide Access to Triggered $\mathrm{H}_{2} \mathrm{~S}$ Donors and Analyte Replacement Fluorescent Probes. J. Am. Chem. Soc. 2016, 138, 7256-7259. [CrossRef]

170. Powell, C.R.; Foster, J.C.; Okyere, B.; Theus, M.H.; Matson, J.B. Therapeutic Delivery of $\mathrm{H}_{2} \mathrm{~S}$ via COS: Small Molecule and Polymeric Donors with Benign Byproducts. J. Am. Chem. Soc. 2016, 138, 13477-13480. [CrossRef] [PubMed]

171. Tao, X.; Deng, Y.; Shen, Z.; Ling, J. Controlled Polymerization of N-Substituted Glycine N-Thiocarboxyanhydrides Initiated by Rare Earth Borohydrides toward Hydrophilic and Hydrophobic Polypeptoids. Macromolecules 2014, 47, 6173-6180. [CrossRef]

172. Zhao, Y.; Pluth, M.D. Hydrogen Sulfide Donors Activated by Reactive Oxygen Species. Angew. Chem. Int. Ed. 2016, 55, 14638-14642. [CrossRef]

173. Dickinson, B.C.; Huynh, C.; Chang, C.J. A Palette of Fluorescent Probes with Varying Emission Colors for Imaging Hydrogen Peroxide Signaling in Living Cells. J. Am. Chem. Soc. 2010, 132, 5906-5915. [CrossRef]

174. Miller, E.W.; Albers, A.E.; Pralle, A.; Isacoff, E.Y.; Chang, C.J. Boronate-Based Fluorescent Probes for Imaging Cellular Hydrogen Peroxide. J. Am. Chem. Soc. 2005, 127, 16652-16659. [CrossRef] [PubMed]

175. Pan, J.; Devarie-Baez, N.O.; Xian, M. Facile Amide Formation viaS-Nitrosothioacids. Org. Lett. 2011, 13, 1092-1094. [CrossRef] 
176. Rao, Y.; Li, X.; Danishefsky, S.J. Thio FCMA Intermediates as Strong Acyl Donors: A General Solution to the Formation of Complex Amide Bonds. J. Am. Chem. Soc. 2009, 131, 12924-12926. [CrossRef] [PubMed]

177. Wang, P.; Danishefshy, S.J. A Promising General Solution to the Problem of Ligating Peptides and Glycopeptides. J. Am. Chem. Soc. 2010, 132, 17045-17051. [CrossRef]

178. Liu, R.; Orgel, L.E. Oxidative Acylation Using Thioacids. Nat. Cell Biol. 1997, 389, 52-54. [CrossRef] [PubMed]

179. Dawson, E.P.; Muir, T.W.; Clark-Lewis, I.; Kent, S.B. Synthesis of Proteins by Native Chemical Ligation. Science 1994, 266, 776-779. [CrossRef]

180. Crich, D.; Sharma, I. Epimerization-Free Block Synthesis of Peptides from Thioacids and Amines with the Sanger and Mukaiyama Reagents. Angew. Chem. Int. Ed. 2009, 48, 2355-2358. [CrossRef]

181. Wu, D.; Hu, Q.; Ma, F.; Zhu, Y.Z. Vasorelaxant Effect of a New Hydrogen Sulfide-Nitric Oxide Conjugated Donor in Isolated Rat Aortic Rings through cGMP Pathway. Oxidative Med. Cell. Longev. 2016, 2016, 1-10. [CrossRef]

182. Liu, C.; Guo, W.; Shi, X.; Kaium, M.; Gu, X.; Zhu, Y.Z. Leonurine-Cysteine Analog Conjugates as a New Class of Multifunctional Anti-myocardial Ischemia Agent. Eur. J. Med. Chem. 2011, 46, 3996-4009. [CrossRef]

183. Ignarro, L.J.; Napoli, C.; Loscalzo, J. Nitric Oxide Donors and Cardiovascular Agents Modulating the Bioactivity of Nitric Oxide: An Overview. Circ. Res. 2002, 90, 21-28. [CrossRef]

184. Xiong, Y.; Chang, L.-L.; Tran, B.; Dai, T.; Zhong, R.; Mao, Y.-C.; Zhu, Y.-Z. ZYZ-803, a Novel Hydrogen SulfiDe-nitric Oxide Conjugated Donor, Promotes Angiogenesis via Cross-Talk between STAT3 and CaMKII. Acta Pharmacol. Sin. 2020, 41, 218-228. [CrossRef]

185. Hu, Q.; Wu, D.; Ma, F.; Yang, S.; Tan, B.; Xin, H.; Gu, X.; Chen, X.; Chen, S.; Mao, Y.; et al. Novel Angiogenic Activity and Molecular Mechanisms of ZYZ-803, a Slow-Releasing Hydrogen Sulfide-Nitric Oxide Hybrid Molecule. Antioxid. Redox Signal. 2016, 25, 498-514. [CrossRef] [PubMed]

186. Wu, D.; Hu, Q.; Xiong, Y.; Zhu, D.; Mao, Y.; Zhu, Y.Z. Novel $\mathrm{H}_{2} \mathrm{~S}-\mathrm{NO}$ Hybrid Molecule (ZYZ-803) Promoted Synergistic Effects Against Heart Failure. Redox Biol. 2018, 15, 243-252. [CrossRef]

187. Bucci, M.; Vellecco, V.; Cantalupo, A.; Brancaleone, V.; Zhou, Z.; Evangelista, S.; Calderone, V.; Papapetropoulos, A.; Cirino, G. Hydrogen Sulfide Accounts for the Peripheral Vascular Effects of Zofenopril Independently of ACE Inhibition. Cardiovasc. Res. 2014, 102, 138-147. [CrossRef]

188. Terzuoli, E.; Monti, M.; Vellecco, V.; Bucci, M.; Cirino, G.; Ziche, M.; Morbidelli, L. Characterization of Zofenoprilat as an Inducer of Functional Angiogenesis through Increased $\mathrm{H}_{2} \mathrm{~S}$ Availability. Br. J. Pharmacol. 2015, 172, 2961-2973. [CrossRef]

189. Monti, M.; Terzuoli, E.; Ziche, M.; Morbidelli, L. The Sulphydryl Containing ACE Inhibitor Zofenoprilat Protects Coronary Endothelium from Doxorubicin-Induced Apoptosis. Pharmacol. Res. 2013, 76, 171-181. [CrossRef] [PubMed]

190. Monti, M.; Terzuoli, E.; Ziche, M.; Morbidelli, L. $\mathrm{H}_{2}$ S Dependent and Independent Anti-inflammatory Activity of Zofenoprilat in Cells of the Vascular Wall. Pharmacol. Res. 2016, 113, 426-437. [CrossRef]

191. Furuta, S.; Kiyosawa, K.; Higuchi, M.; Kasahara, H.; Saito, H.; Shioya, H.; Oguchi, H. Pharmacokinetics of Temocapril, an ACE Inhibitor with Preferential Biliary Excretion, in Patients with Impaired Liver Function. Eur. J. Clin. Pharmacol. 1993, 44, 383-385. [CrossRef] [PubMed]

192. Donnarumma, E.; Ali, M.J.; Rushing, A.M.; Scarborough, A.L.; Bradley, J.M.; Organ, C.L.; Islam, K.N.; Polhemus, D.J.; Evangelista, S.; Cirino, G.; et al. Zofenopril Protects Against Myocardial Ischemia-Reperfusion Injury by Increasing Nitric Oxide and Hydrogen Sulfide Bioavailability. J. Am. Hear. Assoc. 2016, 5, 1-17. [CrossRef] [PubMed] 